\title{
MODERATING EFFECTS OF NATIONAL CULTURE ON THE PSYCHOLOGICAL CONTRACT BREACH AND OUTCOME RELATIONSHIP: A META-ANALYSIS
}

\author{
A. Thushel Jayaweera \\ School of Management, University of Bath, United Kingdom \\ P. Matthijs Bal \\ Lincoln International Business School, University of Lincoln, United Kingdom

\section{Katharina Chudzikowski} \\ School of Management, University of Bath, United Kingdom
}

\section{Simon B. de Jong}

School of Business and Economics, Maastricht University, The Netherlands

This article was accepted by

the Journal of the Cross Cultural \& Strategic Management

on 20-Jan-2021

DOI: $10.1108 / C C S M-07-2020-0137$ 


\section{Purpose}

This paper contains a meta-analysis of the psychological contract literature published in the last two decades. The aim was to investigate the moderating role of national culture in the individual-level relationships between psychological contract breach (PCB) and two important work outcomes, namely job performance (in-role and organizational citizenship behaviors) and turnover (actual and intended).

\section{Design/methodology/approach}

After an extensive literature search, 134 studies were found which matched our aim. We then incorporated national cultural scores based on the GLOBE study to include country-level scores to identify how the PCB relationships with these four outcomes vary across cultures.

\section{Findings}

The findings indicate that national cultural practices moderated the associations between PCB and the four outcomes, yet, no significant moderations for uncertainty avoidance practices.

\section{Originality/value}

While existing research has examined the impact of the breach on work outcomes such as job performance and turnover, there are few empirical studies that examine how national cultural practices influence the relationships between psychological contract breach and job performance and turnover. The authors address this need by investigating and creating a deeper insight into how cultural practices such as institutional collectivism, performance-orientation, power-distance, future-orientation, and gender egalitarianism moderate the relationships between PCB and job performance and turnover.

\section{Keywords}

Psychological contract breach, GLOBE cultural practices, job performance, turnover, metaanalysis

Article classification: Research paper 
PCB AND CULTURE

\section{Introduction}

Managing employee behavior through effective employment relations across cultures is a fundamental challenge for Human Resource Management (Cruz et al., 2018; LuciaCasademunt et al., 2018). Effective employee relations can influence work outcomes such as job performance and turnover (Bal et al., 2008). One relevant concept to understand employee relations is the psychological contract (Rousseau, 1989). A psychological contract refers to the mutual unwritten obligations between an employee and his/her organization. How employee psychological contracts impact employee behavior can vary across cultures (Thomas et al., 2003). This is because perceptions develop in the minds of employees and such perceptions are prone to develop in line with cultural norms and expectations.

Psychological contracts become salient when they are breached (Rousseau, 1989) Psychological contract breach (PCB) refers to employees' perceptions of their organization's failure to fulfill their obligations towards them (Rousseau, 1989). Previous meta-analyses found that there is an association between psychological contract breach and work outcomes such as job performance and turnover (Zhao et al., 2007). Researchers also found that there are various moderators influencing these PCB and outcome relationships (Bal et al., 2008; Zhao et al., 2007). Although there exist some empirical evidence suggesting a possible influence of national culture on PCB (Haybatatollahi and Gyekye, 2015; Kickul et al., 2004; Rousseau and Schalk, 2000), studies exploring the moderating role of national culture on PCB and work outcomes relationship have been rare (Taras et al., 2011), and clear insights are therefore lacking at the moment.

National culture might impact the relationship between psychological contract perceptions and employee performance and turnover. In this paper, we focus on how national culture might alter breach-related work outcomes such as job performance and turnover. Specifically, we will investigate how national cultural practices shape key employee work 
outcomes such as job performance (Jaramillo et al., 2005; Kraimer et al., 2001) and turnover (Luu et al., 2010; Peretz and Fried, 2012) following breach. Cultural practices refer to socially acceptable and routinized individual behaviors (Frese, 2015). In doing so, we build on existing meta-analyses that have examined relationships of PCB with job performance and turnover (Bal et al., 2008; Jayaweera et al., 2020; Zhao et al., 2017). In addition, to understand national cultural practices across a wide variety of countries, we use the GLOBE framework. As it is important to understand how cultural effects inform managerial practices (Nadeem and Sully de Luque, 2017), this article aims to examine the moderating role of national cultural practices based on the GLOBE dimensions (i.e., institutional collectivism, performance-orientation, power distance, future society orientation, uncertainty avoidance, and gender egalitarianism) on the relationships between PCB and job performance and turnover.

We will argue that national cultural practices can shape individual work outcomes (e.g., Autio et al., 2013; Fischer and Mansell, 2009). We focus on two important work outcomes, namely job performance and employee turnover as they are key outcomes that have direct organizational consequences such as organizational performance (Park and Shaw, 2013). Evidence suggests that individual work outcomes are shaped by national culture (Vora et al., 2018). We argue that developing a greater understanding of the impact of national cultural practices on PCB and outcome relationships will provide new insights into PCB research. These insights could further expand our understanding of how national culture might influence PCB-related outcomes at the individual level, an area of research that has not yet received a lot of scholarly attention (Rousseau and Schalk, 2000). In this study, we will assess if national cultural practices moderate the associations between PCB and (in-role and organizational citizenship behaviors) job performance and (actual and intended) turnover. In-role performance refers to the effectiveness of an individual employee to perform formal job tasks and organizational citizenship behaviors (i.e., contextual performance) refer to the ability of an 
individual to perform tasks beyond the formal requirements (see Borman and Motowidlo, 1997). In terms of employee turnover, we focus on turnover intention (refers to as an individual's intention to leave the organization) and actual turnover (refers to an individual leaving the organization).

\section{Theoretical Background}

Broadly speaking, national culture is a higher-order phenomenon that can impact individual behavior (Van de Vijver et al., 2008; Van Hemert et al., 2008; Varela et al., 2010). It is therefore that scholars have advocated for the importance of using a multilevel approach (Alutto, 2002) to understanding the impact of national culture on work outcomes at the individual level (Jaramillo et al., 2005; Kraimer et al., 2001). Empirical research in the PC literature has focused on the impact on national culture at the individual level (Newman and Sheikh, 2012). Research in this area has yet to examine the impact of national culture at the society level on psychological contract breach and work outcome relationships. We contribute to this moving literature by going beyond self-reported national cultural scores by shifting our focus to society-level national culture. We aim to develop a multilevel model to explain how national cultural practices moderate job performance and turnover following PCB.

Although there are various national cultural frameworks that exist in the literature, we focus on GLOBE's cultural framework (House et al., 2004). The GLOBE offers a complete picture of the national culture (Nadeem and Sully de Luque, 2017), and a growing number of scholars have used the GLOBE dimensions because of its methodological rigor and theoretical advancement (Javidan et al., 2006). To understand the impact of national culture on work outcomes, GLOBE asked respondents to indicate their views regarding national culture (i.e., to what extent people in their society follow certain values and practices) to provide a collectivelevel construct (Fischer and Mansell, 2009). Other frameworks, such as Hofstede (1980, 1997, 
2001), asked the respondents to provide their personal views regarding national culture (i.e., what extend do you follow certain values) to establish an aggregate score of national culture leading to ecological fallacy (Oyserman et al., 2002). How GLOBE constructed and measured the distal culture or national culture makes it the best available framework for understanding national cultural practices (Fischer and Mansell, 2009; Javidan et al., 2006) and hence, we follow this framework in our study.

We develop a multilevel framework to understand the impact of national culture on the relationships between breach and work outcomes by engaging in a two-step procedure. At the first stage, we conducted a meta-analysis at the individual level (see, for example, Jayaweera et $a l ., 2020)$. In the second stage, we tested the moderating role of the country's cultural practices, applying the GLOBE framework (House et al., 2004). More specifically, linking to theoretical reasoning within PCB research, we use six of dimensions of GLOBE (House et al., 2004) namely: institutional collectivism practices, performance orientation practices, power distance practices, future orientation practices, uncertainty avoidance practices, gender egalitarianism practices - to investigate the effects of the national cultural practices on PCB-related responses.

This study, therefore, contributes to the PCB literature by showing the differential relationships between specific national cultural practices and specific outcomes. Specifically, this study contributes to our understanding of how national cultural practices such as collectivism practices, performance orientation practices, power-distance practices, future society practices, uncertainty avoidance practices, and gender egalitarianism practices influence breach-related outcomes such as job performance and turnover. Moreover, our study contributes to understanding the practical relevance of culturally contextualizing PCB for managing employments relations across the world. 
PCB AND CULTURE

\section{Theoretical background and hypothesis development}

\section{Psychological contract breach and work outcomes}

Prior literature often explains the relationships between PCB and work outcomes based on Social Exchange Theory (SET; Blau, 1964). According to SET, people engage in exchange relationships to receive inducements for what they provide to another party (Blau, 1964). In case of a breach (i.e., when the employer does not fulfill its obligations in the perceptions of an employee), employees are likely to adapt their behaviors to re-establish a balance in their relationship with the employer.

In a first step, we provide empirical generalizations regarding the link between PCB and job outcomes specifically to gather contemporary evidence regarding the relationship of breach and job performance and turnover. A previous meta-analysis showed a negative relationship between $\mathrm{PCB}$ and job performance and a positive relationship between PCB and employee turnover (Zhao et al., 2007). We will build on these results and investigate the relationships between PCB and job performance and turnover by extending the previous metaanalysis (Zhao et al., 2007). Based on SET, we anticipate PCB to be negatively linked to inrole performance and organizational citizenship behavior (OCB), while being positively linked to turnover intention and actual turnover (Bal et al., 2008; Conway and Briner, 2005; Zhao et al., 2007). Therefore, we expect:

Hypothesis 1: Psychological contract breach is negatively related to in-role performance (H1a) and organizational citizenship behavior (H1b).

Hypothesis 2: Psychological contract breach is positively related to turnover intention (H2a) and actual turnover (H2b). 
National culture, psychological contract breach, and work outcomes

Following previous research, we define national culture as the "shared motives, values, beliefs, identities, and interpretations or meanings of significant events that result from common experiences of members of collectives and are transmitted across age generations" (House et al., 2004, p. 57). National culture includes collective experiences that are conceptualized as the collective programming of mentality found at a national level (Czarnecka et al., 2018; House et al., 2004) that are geographically situated (Parboteeah et al., 2005; Van Hemert et al., 2008). Yet, the national culture that is geographically situated resides in the mind, as nothing can reside outside of the mind (Harvey, 2013; Hodgson, 2011). This view is also supported by social cognitive theory (Bandura,1998, 2002) which suggests that a blend of proximal and distal culture influence an individual's behavior. Empirical evidence based on social cognitive theory has shown that the macro-level national culture shapes individual perceptions and behavior (Stajkovic and Luthans, 1997).

Empirical evidence suggests that psychological contract perceptions differ across societies (Rousseau and Schalk, 2000) and cultures (Sanchez-Burks et al. 2000; Westwood et al. 2001). In general, societal culture plays a role in shaping exchange relations (Levinson, 1965), and there is ample evidence that psychological contracts vary across cultures (Rousseau and Schalk, 2000). For instance, in PC literature, empirical studies have suggested that national culture impact PC perceptions (Thomas et al., 2003; 2010) and that national culture moderates the breach related outcomes such as turnover (Arshad, 2016). Authors have suggested that further research should consider the moderating effects of national culture in influencing breach-related outcomes (Thomas et al., 2016). Mechanisms through which society culture impacts psychological contract breach perceptions at the individual level have been empirically explored to some extent in the PC literature. For example, Thomas and colleagues (2003) suggested that national culture can influence an individual's psychological contract 
formation, and responses to perceived violation through two mechanisms, namely via cognitive and motivational mechanisms. Cognitive mechanisms refer to "those that operate through neuropsychological information processing channel” (Thomas et al., 2003, p. 456) and represent the role played by an individual's mental representation in understanding and organizing information related to people and events happening in society. Individuals in different cultures tend to develop different sets of schemas, which help them organize information in their respective environments (Fiske and Taylor, 1984). Thomas and colleagues (2003) argued that people pay attention to different stimuli and provide different meanings to them based on schemas when dealing with PCB.

Motivational mechanisms refer to mechanisms which "operate through preferable end states or modes of behavior" (Thomas et al., 2003, p. 456). From a motivational perspective, individuals tend to formulate different motives when they form social exchange relations in line with their cultural values. Employee motives, desires, and behaviors are shaped by culturally desirable self-concepts (Fiske and Taylor, 1984). Thus, individuals are motivated to fulfill their desires in line with their culture and this will lead to various behavioral outcomes. Thomas and colleagues $(2003 ; 2010)$ provide two insightful perspectives - the cognitive and motivational one - that enhance our understanding of how culture impacts psychological contract breach. In addition to this, there is a different stream of the literature that proposes a third perspective, namely emotional mechanisms (Markus and Kitayama, 1991; Wilson and Gilbert, 2003). Emotions occur along with cognitive and motivational responses to an event (Scherer, 2009), and refer to “an emergent, dynamic process based on individual's subjective appraisal of significant events" (Scherer, 2009; p.1). Culture shapes how an individual experiences emotion or expresses them (Lim, 2016; Turner and Stets, 2005). Therefore, we propose that the ways how individual experience emotion and display emotions are shaped by 
cultural concerns and might affect PCB's relationship with key work behaviors, alongside the above mentioned cognitive and motivational mechanisms.

Prior research has used multi-level theorizing to show that national culture can influence individual behavior (Fisher, 2009; Van de Vijver et al., 2008). More specifically, researchers have used national culture framework, such as GLOBE, as the key determinant of work practices (Ali and Brooks, 2008; Parboteeah et al., 2005) and have commonly argued that there is a direct path linking national culture with individual-level behavior (Fischer et al., 2005; Stamkou et al., 2019). When linking national culture as a society level concept to individual work outcomes, previous scholars have established the view that the effects of national culture on an individual's work-related activity is shaped by societal norms, which people in a society share (Hofstede, 2001; Mu et al., 2015). Besides, society norms associated with national cultures can play a key role in shaping psychological contract perceptions (Rousseau and Schalk, 2000). Social norms refer to the informal, rules that people in society find acceptable and appropriate, and obligatory to follow (Cislaghi and Heise, 2018). Moreover, national culture impacts social structures, and social roles which guide cultural practices at work (Chiu et al., 2010; Cislaghi and Heise, 2018; Kinias et al., 2014).

\section{The GLOBE framework of national culture}

We draw on the GLOBE cultural framework (House et al., 2004) to understand the impact of national culture on PCB responses. This is because the GLOBE offers theoretically, sound, empirically acceptable, cross-culturally developed, and comprehensive constructs and scales that are suitable for cross-cultural studies (Javidan et al., 2006). The GLOBE's constructs are suitable for this study because the properties of the construct are manifested at an aggregate level of analysis (i.e., society level) (see Javidan et al., 2006). The GLOBE considers two aspects: values (society values) and practices (society practices). Society practices measure 
perceived practices as it is (House et al., 2004). Society values are respondents' beliefs about how things should be organized in their society (House et al., 2004). Previous scholars have often looked at values alone assuming that understanding the values of culture is merely enough to understand or predict practices or what really happens in society (Javidan et al., 2006). The GLOBE's decision to incorporate a practice dimension allows us to understand how societal practices impact behaviors at work. Substantial evidence has reported that the practice dimensions of the GLOBE have greater validity than its value dimensions in predicting behaviors (Fischer and Schwartz, 2011). Practices also have their meaning firmly at the societal level, whilst values can also contain an individual-level component (Chao et al., 2011; Cullen et al., 2004). Furthermore, evidence suggests that cultural practices are more likely than values to impact work outcomes (Parboteeah et al., 2005; Smith, 2006). Therefore, GLOBE's practice dimensions are appropriate to understand the moderating impact of culture on an individual's work outcomes following PCB. Below, we will argue that six GLOBE dimensions (i.e., institutional collectivism, performance-orientation, power distance, future society orientation, uncertainty avoidance, and gender egalitarianism) are relevant in relation to PCB.

\section{Moderating effects of cultural practices}

\section{Institutional collectivism practices, $P C B$, and work behaviors}

Institutional collectivism practices refer to "the degree to which organizational and societal institutional practices encourage and reward collective distribution of resources and collective action" (House et al., 2004, p.30). Societies high in institutional collectivism encourage and reward collective action among people who live in such societies. In contrast, people who live in individualist societies encourage and reward personal needs, individual rights even at the expense of group loyalty (Peretz et al., 2015). Evidence suggests that employees who live in 
collectivist societies tend to have stronger psychological contracts with their employers and are less willing to underperform or leave despite personal dissatisfaction (Maertz, 2004). In contrast, employees who live in individualist societies tend to have weaker psychological contracts with their employers (Cruz et al., 2018; Thomas et al., 2003).

Studies have also shown that collectivism impacts job performance (Varela et al., 2010) and turnover (Clinton and Guest, 2013). Similarly, empirical evidence has suggested that higher performance and lower turnover is found in countries where social norms oppose going against managerial practices (Chen et al., 2007). In general, collectivist societies tend to discourage an employee from deviating from their respective group of reference including managers and colleagues (Fischer and Mansell, 2009) and therefore, they are more likely to be tolerant to breach. Social norms and roles in collectivist societies encourage managers and employees to position themselves as belonging to groups and organizations they work for (Cohen and Hill, 2007; Thomas et al., 2003; 2010). These distinctions suggest that individuals in collectivistic societies are more likely to emphasize group commonality (Cohen et al., 2016). As a result, they are likely to react less strongly to breach by underperforming or leaving their jobs in comparison to the individuals who live in individualist societies. Thus, in line with our theoretical positioning, and previous studies (e.g. Thomas et al., 2003), we expect that individuals in collectivistic cultures will be more tolerant of PCB and will respond more favorably by being more tolerant to breach than those who live in less collectivist cultures. We therefore hypothesize:

Hypothesis 3: Institutional collectivism practices moderate the relationship between PCB and work behaviors. More specifically, relationships will be less negative for inrole performance (H3a) and organizational citizenship behavior (H3b), and less positive for turnover intentions $(\mathbf{H 3 c})$ and actual turnover $(\mathbf{H 3 d})$, the higher the levels of institutional collectivism practices. 
Performance orientation practices, $P C B$, and work behaviors

In the GLOBE framework, performance-orientation practices refer to the degree to which a society encourages excellent performance and innovation practices (House et al., 2004). Performance oriented societies appreciate individuals who produce results (House et al., 2004; Javidan et al., 2006; Thomas et al., 2003). Societies high in performance orientation are likely to emphasize the importance of training and feedback to improve performance (Messner and Rosenfeld, 2001; Rabl et al., 2014). Similarly, people who live in high performance-oriented societies care about achieving professional success (Cullen et al., 2004; Newburry \& Yakova, 2006). In contrast, employees who live in low performance-oriented societies tend to care less about the competition (Rabl et al., 2014).

Given that recognition is given for high performance (Daumiller and Janke, 2019), employees might still be encouraged to perform better following a breach in high-performance societies (Rabl et al., 2014). In contrast, in low-performance-oriented societies, limited recognition is given of employee title, salary, and achievement (Salamin and Hom, 2005). These practices might hinder employee performance (Nanda and Sorensen, 2010). In addition, in high performance orientation societies, employees tend to strive to find better jobs associate with higher turnover (Salamin and Hom, 2005). In contrast, low performance orientation societies emphasize harmony over performance (Thomas et al., 2003) and are likely not to challenge employees for underperforming or quitting (Rahman et al., 2017). Performance orientation practices also have a direct link with work outcomes such as performance (Jackofsky, 1987) and turnover (Sturman et al., 2012).

Therefore, based on social cognitive theory (Bandura, 1998; Stajkovic and Luthans, 1997) and above reasoning, we argue that individuals who live in low performance societies are less likely to improve performance following breach. On the contrary, it follows that in the event of breach, employees who live high performance societies tend to set ambitious goals 
and still perform well in the event of breach and are less likely to leave their jobs. Thus, we expect that people who are exposed to high-performance orientation practices will respond less negatively to PCB than those who are exposed to low-performance orientation cultural practices. We therefore hypothesize:

Hypothesis 4: Performance orientation practices moderate the relationship between PCB and work behaviors. More specifically, relationships will be less negative for inrole performance (H4a) and organizational citizenship behavior (H4b), and less positive for turnover intention (H4c) and actual turnover (H4d), the higher the levels of performance orientation practices.

\section{Power distance practices, $P C B$, and work behaviors}

In the GLOBE framework, power distance practices refer to "the extent to which the community accepts and endorses authority, power differences, and status privileges" (House et al., 2004). Accordingly, in societies that have high power distance practices, the social norms of the society are that the followers are expected to obey the commands of their leaders without questioning any of their actions (Daniels and Greguras, 2014; Ghosh, 2011; House et al., 2004). Similarly, people who live-in high-power distance societies experience a vertical subordinate-supervisor relationship at work (Carl et al., 2004). In contrast, people who live in low-power distance societies expect that people will display less obedience to authority in the workplace (Praboteeah et al., 2005; Rao and Pearce, 2016).

Power distance practices can have an impact on work behaviors (Heales et al., 2004; Khatri, 2009). Research in high power distance societies has shown that senior employees possess more autonomy over decision making (Earley and Erez, 1997; Sturman et al., 2012). Empirical evidence suggests that people who live in societies with high power distance are more tolerant to poor employment relations and are not expected to negotiate at work (Herriot 
and Stickland, 1997) in comparison to those who live in low power distance societies (Haybatatollahi and Gyekye, 2015; Sturman et al., 2012). Moreover, research has shown that those who value power and authority are likely to put more efforts in maintaining better relationships with the leaders (Ghosh, 2011) and prefer to follow leaders passively (Khatri, 2009) and this might lead to employees putting more efforts into increasing job performance (Gul et al., 2018; Rafiei and Pourreza, 2013) and reducing voluntary turnover. Besides, management practices in high power distance societies would restrict underperformance and voluntary turnover (Gul et al., 2018; Rafiei and Pourreza, 2013).

A few studies have indicated that power distance is associated with PCB (Thomas et al., 2003) and breach responses (Vantilborgh et al., 2013; Zagenczyk et al., 2015). In higher power distance societies, employees are more likely to accept managerial decisions and respect authority (Daniels and Greguras, 2014; Ghosh, 2011) even when they experience negative events at work. In contrast, employees in low-power distance societies are more likely to react strongly to breach as they are less likely to respect authority (Parboteeah et al., 2005). Typically, stronger reactions to breach would indicate lowering performance and increasing voluntary turnover. Thus, we hypothesize that those who live in high-power distance societies are more likely to display higher job performance and lower turnover in responding to breach when compared to low power distance countries. We hypothesize:

Hypothesis 5: Power distance practices moderate the relationship between PCB and inrole performance (H5a), organizational citizenship behavior (H5b), turnover intention (H5c) and actual turnover (H5d). Relations will be less negative (in-role performance, organizational citizenship behavior), and less positive (turnover intention, turnover), the higher the levels of power distance practices. 
Future orientation practices, $P C B$, and work behaviors

Future orientation refers to the degree to which society collectively encourages and rewards future-oriented behaviors such as planning and delaying gratification (House et al., 2004). In societies high in future orientation, individuals tend to plan for the future (Trommsdorff, 1983) and give priority to long-term success (Grove, 2005). In future-oriented societies, individuals prefer longer-term gain rather than shorter-term gain (Orpen, 1995, Palthe, 2014). In contrast, individuals who live in low future-oriented societies are less willing to invest in long term prospects and are more interested in the present (Aspinwall, 2005; Aspinwall and Leaf, 2002). Social norms of future-oriented culture direct individuals towards achieving future goals (Kucharska and Bedford, 2019).

People who live in high future-oriented societies are likely to feel more job insecurity at work following negative work experiences (De Hauw and De Vos, 2010; Peretz et al., 2017). Lack of job security can significantly reduce job performance or increase turnover (Avital, 2000; Pettigrew, 1997). Future-oriented individuals are more likely to be make conscious decisions favorable to their career growths (Qian et al., 2015). Individual career goals shape how an individual responds to a breach (Aspinwall, 2005; Sadowski and Schranger, 2016). PCB is a future risk, as it means that past promises were not kept and that future promises might thus also not be kept, motivating individuals to pursue other career goals and change their existing jobs (Schrager and Sadowski, 2016) and reduce job performance (Lu and Lin, 2014). Similarly, PCB can be seen as an obstacle for long-term career growth, promotion, and success (De Hauw and De Vos, 2010). Consequently, individuals who live in future-oriented societies are more likely than individuals who live in societies embedded in the present, to pursue actions to restore balance in breach in the interest of their own career growth and development. Restoring balance in replying to PCB indicates lowering performance and increasing turnover (Zhao et al., 2007). Thus, we expect that those who live in cultures that 
encourage them to plan for the future will have lower levels of job performance and higher levels of turnover following PCB, in comparison to those individuals who live in cultures that encourage less to plan for the future. Our sixth set of hypotheses reads:

Hypothesis 6: Future orientation practices moderate the relationship between PCB and key work behaviors. More specifically, relationships will be more negative for in-role performance (H6a) and organizational citizenship behavior (H6b), and more positive for turnover intention (H6c) and actual turnover (H6d), the higher the levels of future orientation practices.

Uncertainty avoidance practices, $P C B$, and work behaviors

Uncertainty avoidance refers to the degree to which ambiguous and uncertain situations are threatening to individuals, to which predicted ordered are preferred (House et al., 2004). People who live in societies with high uncertainty avoidance prefer to take fewer risks (Parboteeah et al., 2005), trust in others (Hwang, 2009), and are likely to feel more uncomfortable in unknown or surprising situations (Ozorio et al., 2010) in comparison to those who live in low uncertainty avoidance societies (House et al., 2004).

Uncertainty avoidance societies often adopt rules and norms to manage uncertain situations (Hwang, 2009). Individuals who live in high-uncertainty-avoidant societies tend to avoid considering information that would seem ambiguous in favor of verifiable data such as seniority (Fischer, 2009). Research evidence suggests that people who live in societies with high uncertainty avoidance tend to have social norms that encourage people to experience more anxiousness when faced with unexpected situations (Krasnova et al., 2012). Individuals who want to avoid risks such as potential loss of existing employment (Sturman et al., 2012), will remain more tolerant to negative work events (Kalleberg, 2009; Rispens and Demerouti, 2016). 
Given that performance and turnover decisions involve some degree of uncertainty related to things involved such as for pay (Bauer et al., 2007), promotions, and relationships with co-workers and supervisors (Allen et al., 2005), and advancement opportunities, employees who live in high-uncertainty-avoidant societies would see performance issues and voluntary turnover as less desirable (Maertz, 2004). Individuals who live in high-uncertainty avoidance societies are more likely, relative to individuals who live in low-uncertainty avoidance societies do not like situations that avoid ambiguity, and therefore are less likely to underperform or leave their organizations following breach as both underperforming and leaving the job to indicate a certain degree of uncertainty (Peretz et al., 2017). Research has confirmed that in societies which are high uncertainty avoidance, decreasing performance (Sturman et al., 2012) as resistance to management and voluntary turnover is undesirable (Maertz, 2004). Thus, we expect when a society favors consistency and orderliness, it is likely that individuals implement strategies to manage PCB and try to maintain performance and avoid turnover. We therefore hypothesize:

Hypothesis 7: Uncertainty avoidance practices moderate the relationship between PCB and work behaviors. More specifically, relationships will be more negative for in-role performance (H7a) and organizational citizenship behavior $(\mathbf{H 7 b})$, and more positive for turnover intention $(\mathbf{H 7 c})$ and actual turnover $(\mathbf{H 7 d})$, the lower the levels of uncertainty avoidance practices.

Gender egalitarianism practices, $P C B$, and work behaviors

One of the often-neglected dimensions of GLOBE framework is gender egalitarianism, which refers to "the degree to which a collective minimizes gender inequality" (House et al., 2004). Gender egalitarianism is reflected in social norms that set limits for what men and women can do (Burda et al., 2007; Lyness and Judiesch, 2014) and can shape gender roles 
among people (Grove, 2005; Lyness and Judiesch, 2014). Gender egalitarian societies encourage power, and appreciate the worth of other people by building participation (Rosner, 1990). Moreover, in such societies, managers encourage members to perform well by lowering competition (Betz et al., 1989).

Gender-egalitarian societies might be linked to high-performance organizations (Burda et al., 2013; Gupta, 2011) and increased turnover among employees (Camgoz et al., 2016). Individuals who live in high gender-egalitarian societies tend to have fewer differences in the way in which they allocate roles for men and women (Emrich et al., 2004). Furthermore, people who live in high gender-egalitarian societies tend to formalize relationships and take precedence over satisfaction derived from achieving job tasks. In contrast, employees from low-gender egalitarian societies believe that loyalty to their supervisors is more important than completing job obligations (Gupta, 2011). People in low gender-egalitarian society are generally loyal to their employers (Gupta, 2011) and might be more tolerant to breach. Given that breach indicates a failure to fulfil obligations indicating a state of poor formal relationship with the organization, following a breach, people in a high gender-egalitarian society might react more strongly to breach by lowing performance and increasing turnover in comparison to societies that are not gender-egalitarian. More specifically, we hypothesize:

Hypothesis 8: Gender egalitarianism practices moderate the relationship between psychological contract breach and key work behaviors. More specifically, relationships will be more negative for in-role performance (H8a) and organizational citizenship behavior (H8b), and more positive for turnover intention $(\mathbf{H 8 c})$ and actual turnover (H8d), the higher the levels of gender egalitarianism practices. 
PCB AND CULTURE

\section{Methods}

Meta-analytic search strategy and coding procedure

We adopted meta-analysis to examine our model and we used several complementary steps to collect relevant studies. We used the following search strategy to identify studies measuring "psychological contract breach" from the studies that were conducted from the 1980s to 2019 (since the first empirical studies on PCB were published; Rousseau, 1989). We searched the key databases of Web of Science, PsycINFO, EBSCO, and Google Scholar for studies. Akin to prior meta-analyses, we also searched manually through OB and HRM journals. We also retrieved studies from the reference lists of previous meta-analyses (Bal et al., 2008; Zhao et al., 2007), and also searched for available Ph.D. theses. We contacted members of both the OB and HRM divisions of the Academy of Management requesting unpublished studies. As a final check, we contact the authors who published abstract papers on psychological contract breach at the Academy of Management or Society of Industrial and Organizational Psychology meetings and requested unpublished papers.

To be included a study must report psychological contract breach or fulfillment. We initially identified 2,897 studies. Second, we retained only empirical studies, and this resulted in 2,436 studies. Third, we retained only those following quantitative methods, resulting in 2,088 studies. Fourth, we retained those studies that investigated PCB or fulfillment, and this resulted in 1,791 studies. Fifth, we removed duplicates and retained 838 articles. Sixth, only studies measuring the relations between PCB and fulfillment and the relevant work outcomes (in-role performance, $\mathrm{OCB}$, turnover intention, and/or actual turnover) were included, and this resulted in 205 studies. Seventh, only the studies reporting in English, French, or Dutch were included, and we retained 172 studies. Finally, only studies that reported the statistical information that was required to calculate the necessary correlations were included, and eventually, the above exclusions resulted in a final set of 134 studies based on 95 published 
articles. Since the 95 published articles reported more than one variable, in total, we found 34 studies reporting in-role performance, 33 studies reporting citizenship behavior, 61 studies reporting turnover intention, and 6 studies reporting actual turnover. As proposed by Hunter and Schmidt (2004), when multiple sample data that are presented in a single paper, we treated these samples as separate studies by assuming that samples are independent in the metaanalysis.

A coding protocol was designed to record information about the study (author, publication date, the actual date of publication), sample (sample size, sample type, industry, country, demographic characteristics), measurement (mean, standard deviation, reliability) and, effect size (correlation). In PC literature, many studies have used the term breach, fulfilment, and violation interchangeably; therefore, we relied on measurements used by the original authors to identify psychological contract breach to guide our coding. We followed Hunter and Schmidt (2004)'s formulas to calculate the composite correlations and reliabilities between the breach and the selected work outcomes. We computed composite scores ${ }^{1}$ when studies were longitudinal studies reporting correlations over time or when studies were reporting multi-dimensions of the psychological contract.

The first and second authors coded all of the 134 studies (based on 95 independent research papers) and we calculated interrater reliability estimates. Among the authors, a 99 percent agreement on study characteristics and a 99 percent agreement on study numbers were reached. After three months, we checked all recorded information and we identifies few discrepancies (less than 1\%) and solved through discussions (Geyskens et al., 2006).

Measures

${ }^{1}$ There were 15 longitudinal studies in our database, and 4 studies reporting different dimensions of a breach, please refer to Annex 2 . 
When breach or fulfillment was measured in a study it was included and coded. Akin to the meta-analysis of Zhao and colleagues (2007), we reversed the signs of the correlations between fulfillment and job behaviors to indicate psychological contract breach. Measures of psychological contract violation were not included, as it is treated as a separate concept from the breach in the psychological contract literature (Morrison and Robinson, 1997). When multiple dimensions of breach or fulfillment were measured in a single study, a composite score was calculated using the formulas of Hunter and Schmidt (2004). Longitudinal studies typically reported findings at various time points and we, therefore, examined the correlations between the effects sizes across various time points for those studies.

In-role performance was coded when the performance outcome measure of a study reflected an employee performing activities that are directly contributing to the technical core of a job or one's in-role tasks (Borman and Motowildo, 1997). OCBs were coded as any extrarole performance that is not part of the core task description (e.g., Coyle-Shapiro, 2002). Composite correlations were calculated if one of these was measured using multi-dimensional scales. Turnover intentions were coded as intentions of employees leaving their positions and actual turnover was measured following employees leaving their positions (Schyns et al., 2007). Globe cultural practices scores were measured as given in House et al. (2004) as the practices (not values) per country.

\section{Statistical procedure}

The formulas of Hunter and Schmidt (2004) were used to test the hypotheses. We applied the Fisher Z-transformation to all correlations. We tested our hypotheses using SPSS. Moderator analysis in the meta-analysis was conducted using a Weighted Least Squares (WLS) estimation. This is because Weighted Least Squares (WLS) estimation allowed us to correct 
PCB AND CULTURE

for differences between sample sizes, as well as unreliability in the variables measured (Hunter \& Schmidt, 2004).

\section{Results}

Our first aim was to assess overall effect sizes by looking at the correlations between PCB and the four work behaviors (i.e., in role-performance, citizenship behavior, turnover intention, actual turnover). Table 1 shows the results of the main-effects meta-analysis. Truescore correlations are reported, as well as those reported in the Zhao and colleagues (2007) meta-analysis for comparison purposes. Zhao and colleagues (2007) found that PCB was negatively related to in-role performance and OCB and positively to turnover intention and actual turnover. We found similar effects, as PCB significantly related to in-role performance (true score correlation $\rho=-.22)$, citizenship behavior $(\rho=-.24)$, turnover intention $(\rho=.34)$ and actual turnover $(\rho=.18)$. As can be seen in Table 1 , none of the $95 \%$ confidence intervals contained zero indicating that all of these correlations were significant. It is notable how the correlations between PCB and job performance and turnover intentions are quite similar to the Zhao and colleague's (2007) meta-analysis, while the correlations between PCB and OCB and turnover are considerably larger in the current meta-analysis. Lastly, while none of our confidence intervals contained zero, actual turnover did contain zero in Zhao and colleagues (2007). In sum, our findings are thus largely similar to Zhao et al. (2007), although our study includes more studies (e.g., for turnover-intentions we have almost 3 times as many studies than Zhao et al.) as well as more recent studies and thus updates and sharpens contemporary knowledge.

Insert Table 1 about here 
After assessing the main effects, we investigated the moderation effects (Table 2). For moderation to be possible, there needs to be heterogeneity in the findings and the last three columns of Table 2 shows that Q-statistics are all sizeable (Hunter and Schmidt, 2004). Table 2 shows that a nation's institutional collectivism practices moderated the relationship between PCB and in-role performance $(\beta=.37, \mathrm{p}<.05), \operatorname{OCB}(\beta=.37, \mathrm{p}<.05)$, and turnover intention $(\beta=-.29, \mathrm{p}<.05)$. Institutional collectivism practices did not moderate the relationship between contract breach and actual turnover $(\beta=-.81, n s)$, yet this moderation effect approached significance ( $\mathrm{p}=.052)$ and might thus be something to investigate in the future research. Given that the correlations between PCB and in-role performance and OCB are negative (see table 1), the positive beta indicates that negative correlation between PCB and in-role performance ( $\beta$ $=.37, \mathrm{p}<.05)$, as well as the negative correlation between breach and citizenship behavior $(\beta$ $=.37, \mathrm{p}<.05)$, becomes smaller when their institutional collectivism practices are higher. Given that the correlation between PCB and turnover intention is positive (see table 1), the negative beta indicates that that positive correlation between breach and turnover intention $(\beta=-.28, \mathrm{p}<$ .05) becomes smaller when institutional collectivism practices are higher. Overall, these findings provide substantial support for $\mathrm{H} 3$, by showing that institutional collectivism practices can shape the PCB to work outcome relationships.

Performance orientation practices did not moderate the relationship between PCB and in-role performance $(\beta=.33$, ns), yet this effect approached significance $(p=.058)$ and might thus be something for future research. Performance orientation practices significantly moderated the relationship between PCB and OCB $(\beta=.40 \mathrm{p}<.05)$. Given that the correlation between PCB and OCB is negative (see table 1), the positive beta indicates that the negative correlation between PCB and OCB $(\beta=-.24, \mathrm{p}<.05)$ becomes smaller when high-performance orientation practices are higher. However, performance orientation practices did not moderate the relationship between contract breach and turnover intention $(\beta=-.03$, ns) and actual 
turnover $(\beta=.04, \mathrm{~ns})$. Overall, these findings provide some support for $\mathrm{H} 4$, by showing that performance orientation practices can shape the PCB to (extra-role) performance outcome relationships.

Power-distance practices moderated the relationship between PCB and in-role performance $(\beta=.37, \mathrm{p}<.05)$. Given that the correlation between the breach and in-role performance is negative (see table 1), the positive beta indicates (table 4) that negative correlation between the breach and in-role performance $(\beta=.37, \mathrm{p}<.05)$ becomes smaller when power-distance practices are higher. However, power-distance practices did not moderate the relation between PCB and OCB behavior $(\beta=.27$, ns), turnover intention $(\beta=-.23$, ns), and actual turnover $(\beta=.59, \mathrm{~ns})$. Although for turnover intentions the significance level approached significance $(\mathrm{p}=.069)$ and this might thus be something or future research to investigate further. Overall, these findings provide some support for $\mathrm{H} 5$, by showing that power-distance practices can shape the PCB to in-role performance outcome relationship.

Future society practices moderated the relationship between PCB and in-role performance $(\beta=-.35, \mathrm{p}<.05)$, turnover intention $(\beta=.27, \mathrm{p}<.05)$, and actual turnover $(\beta=.90$, $\mathrm{p}<.05)$. Future society practices did not moderate the relationship between contract breach and citizenship behavior $(\beta=.08, n s)$. Given that the correlation between PCB and in-role performance is negative (see table 1), the positive beta indicates that negative correlation between PCB and in-role performance $(\beta=-.35, \mathrm{p}<.05)$ becomes larger when future society practices are higher. Given that the correlations between PCB and turnover intentions and turnover are positive, the positive beta indicates that these positive relations become larger when future society practices are higher. Overall, these findings provide substantial support H6, by showing that future society practices can shape the PCB to work outcome relationships. 
Uncertainty avoidance practices did not moderate the relationship between PCB and in-role performance $(\beta=.18, n s)$, OCB $(\beta=.24, n s)$, turnover intention $(\beta=.08 n s)$, and actual turnover $(\beta=-.49, n s)$. Overall, $\mathrm{H} 7$ is therefore not supported.

Gender egalitarianism practices moderated the relationship between PCB and in-role performance $(\beta=-.44, p<.01)$ and turnover intention $(\beta=26, p<.05)$. Given that the correlation between PCB and in-role performance is negative (see table 1), the negative beta indicates this negative correlation becomes larger when gender egalitarianism is higher. Given that the correlation between breach and turnover intention is positive (see table 1), the positive beta indicates that this positive correlation becomes larger when gender egalitarianism is higher. Gender egalitarianism practices did not moderate the relationship between PCB and OCB $(\beta=$ $-.33, n s)$, and actual turnover $(\beta=-.49, \mathrm{~ns})$. However, for OCB it approached significance $(\mathrm{p}=.058)$ and future research might thus want to investigate this. Overall, these findings provide partial support for H8.

\section{Discussion}

Our findings show that psychological contract breach (PCB) is strongly linked to key work outcomes (i.e., in-role performance, OCBs, turnover intentions, and actual turnover) based on most up to date PCB studies in the literature. Most importantly, the novel findings of our study are that the cultural practices moderate the PCB and work outcome relationship. Previous studies have found that cultural differences such as institutional collectivism and power distance can influence breach-related work outcomes. For example, Kickul and colleagues (2004) found that the association between PCB and job performance and turnover differed across cultures based on data collected from employees from Hong Kong and the US. Zagenczyk and colleagues (2015) found that power distance moderated the association between breach and turnover based on 180 full-time employees using a survey from the USA. Our 
findings expand those findings and add a new contribution to the literature. Firstly, our study examined the impact of six cultural dimensions, namely: institutional collectivism practices, performance orientation practices, power distance practices, future orientation practices, uncertainty avoidance practices, and gender egalitarianism practices. In doing so, we focused on understanding their moderating impact on the relationships of PCB with job performance and turnover. Second, we used meta-analytic techniques as opposed to survey methods used by previously, and this allowed us to use a large, international dataset to increase statistical power to detect moderating effects of cultural practices on breach-related job performance and turnover. Third, most of the previous studies have measured individual-level culture perceptions but we examined society-level cultural scores in this study.

Based on the GLOBE's cultural dimensions, this study revealed that national cultural practices indeed moderate the relationships between PCB and work outcomes as we expected. Specifically, we expected people to be less affected by PCB when there are higher institutional collectivism practices, performance-oriented practices, and power-distance practices. Moreover, we expect people to be more strongly affected by a breach when there are higher future-orientation practices, uncertainty practices, and gender egalitarianism practices. Overall, our results support the notion that society's cultural practices can shape PCB-to-work-behavior relationships, although some specific relationships were found to be non-significant.

Most strikingly, we found that almost all of the four relationships between PCB and the work behaviors were moderated by institutional collectivism, while none were moderated by uncertainty avoidance practices. This can be explained based on social cognitive theory (Albert, 1998) which suggests that personal and environmental factors influence behavior bidirectionally. It may be that employees are influenced by environmental factors other than their distal cultures such as economic and political factors (Behery et al., 2016). For example, empirical evidence suggests that macro-economic factors shape employee behaviors following 
a breach (Behery et al., 2016). Besides, personal factors such as proximal goals (intentions) and expectations (Bandura, 1986) might have impacted employee behaviors. For example, it may well be due to proximal cultural factors (Bandura, 1998), organizational politics, or family circumstances (Azim et al., 2015; Kiewitz et al., 2009) and also due to various other demographic factors (Bal et al., 2008).

Our study combined individual-level data with country-level data, thereby adding multi-level sources of information to understand PCB effects, which is, to our knowledge, the first time this has been done. It is important to understand the impact of national culture specifically, because evidence suggests that national culture is a key determinant of work perceptions (Thomas et al., 2003) and outcomes (Papademetriou and Masouras, 2014). In addition, culture at the national level might impact individual work outcomes differently than the culture at the organizational level or the individual level (Palthe, 2014; House et al., 2004). Therefore, future research could explore the impact of national culture (at the individual level) on work outcomes (Papademetriou and Masouras, 2014) by using multi-level models (Fischer et al., 2005).

\section{Theoretical implications}

Our study provides several theoretical implications. First, psychological contract research has primarily assumed that psychological contract evaluations are influenced by people's immediate environment (e.g., Morrison and Robinson, 1997), individual perceptions of culture (Aldossari, 2016; Thomas et al., 2003; 2010), or organizational culture (Chen et al., 2007). However, our findings indicate that societal-cultural practices can influence work outcomes in line with more general literature that found national cultural practices can shape individual work outcomes (e.g., Autio et al., 2013; Fischer and Mansell, 2009; Markus and Kitayama, 1991). Our findings show that national cultural practices shape individual work 
outcomes and we suggest that these findings should be taken into account in future PCB research. More specifically, our findings reveal the impact of national cultural practices may not follow a uniform pattern in how they signal to individuals how they are expected to cope with psychological contract breaches but may depend on the type of cultural dimension and the specific job behavior. Based on our findings, we suggest that psychological contract theory would benefit from taking a wider perspective on the coping processes of people following the breach and incorporate national cultural dimensions into consideration.

Moreover, our study also offers implications for HRM literature. There is now increasing evidence that individual decision making does not just occur in isolation, but is increasingly dependent on the context (Johns, 2018). Our findings show that a nation's institutional collectivism practices moderated the relationship between PCB and in-role performance and turnover intention of employees. Previous studies have examined cultural values particularly focusing on individualism and collectivism dimensions (Thomas et al., 2003; 2010). However, the impact on other cultural practices at the society level was not well understood. Our study addresses these limitations by developing a multi-level theoretical framework to establish an association between national culture and PCB and work outcomes. There has been some indication that performance orientation impacts psychological contract perceptions (Rahman et al., 2017), and in line with previous findings, our findings indicate that performance orientation practices significantly moderated the relationship between PCB and OCB of employees. Interestingly, the novel findings of our study show that future society practices and gender egalitarianism practices moderated the breach related job performance and turnover. We encourage future researchers to explore how future society practices and gender egalitarianism practices might differ across various industries and individuals. However, as opposed to what we expected, uncertainty avoidance practices did not moderate the breach related job performance and turnover. 
In sum, we recommend that $\mathrm{PCB}$ researchers consider national culture when theorizing the effects of a breach on work outcomes. We suggest that it is crucial to understand the impact of national cultural practices because cultural practices profoundly influence how people feel, behave, and make a decision in the workplace (Bal and Dóci, 2018). In addition, we suggest that future researchers could explore how national cultural practices at both distal (societylevel) and proximal level (individual-level) might influence PCB-related work outcomes.

\section{Limitations, and suggestions}

Despite the strengths, our study has limitations. One limitation is that our sample size for actual turnover is derived from a small sample. This is because PC scholars have traditionally paid little attention to understanding the impact of PCB on actual turnover, but we included this variable because some evidence suggested that the national culture might impact turnover intention and actual turnover differently (Wong and Cheng, 2019). Actual turnover can have a relatively strong impact on organizational consequences such as performance and cost (Wong and Cheng, 2019). Moreover, the turnover intention might have or might not have a link with the actual turnover of people following breach across societies. Therefore, given the limited number of studies available at present, we urge future researchers to pay more attention to understanding how national cultural practices might impact breach-related actual turnover. Besides, we recommend exploring the possible connection between national cultural practices with both turnover intention and turnover following a breach. Also, how national culture might impact breach-related to other work outcomes beyond job performance and turnover warrant further investigations.

Second, we did not examine the impact of culture at the group level on work outcomes. However, examining the cultural impact across broad levels can impede the possibility of exploring specific predictions about when and how national culture matters to understand 
individual-level outcomes. Therefore, this study attempted to examine the impact of national culture on the associations between the breach and individual job behaviors. However, we encourage future researchers to explore these areas.

Third, by applying a multi-level model, we assumed that national culture can impact individual level work outcomes via a direct distal path in line with previous researchers (Van der Vijver et al., 2008). This approach is particularly useful in providing insights when there is an absence of individual scores to measure individual-level cultural scores (Parboteeah et al., 2005). It would be interesting to explore how the distal path fits with the proximal path (i.e., the impact of national culture at the individual level on breach-related work outcome across countries), and this is an area for future research. Besides, there may be various mechanisms through how national culture directly or indirectly impact work outcomes. We suggest that future researchers could explore these areas. Fourth, national culture may be subject to change over time (Oyserman et al., 2002). We treated distal culture as permanent enough to allow us to understand its consequences on the associations between breach and work outcomes. We recommend future researchers to consider exploring temporal factors in understanding the national cultural impact on individual-level work outcomes.

\section{Practical implications and conclusions}

Previous studies have shown that employee outcomes such as performance and turnover are influenced by the national culture (Doellegast and Marsden, 2018; Johnson and Meade, 2010; Pudelko, 2006). In line with previous studies (see for example Kickul et al., 2004), our study shows that while generally, PCB is negatively related to performance-related outcomes, and positively with turnover (intentions), these relationships are contingent upon the general state of the cultural practices at the country level as suggested by scholars (Lelchook and Sully de Luque, 2015). Thus, organizations and managers should be aware that employees 
may respond differently to $\mathrm{PCB}$ depending on their culture. Understanding how different cultural practices shape employee breach-related outcomes can help global managers to better understand managing employee job performance and turnover across cultures.

International managers tend to assume that one policy would suit all organizations that operate across cultures in managing employment relations (Edwards et al., 2019). However, the practice of designing management policies centrally must be done with caution while allowing the flexibility to incorporate local management practices that suit local context based on national cultural context. There are many lessons we can draw from this study and also lessons for managerial implications and practice.

Our findings show that people who live in low-collectivist societies such as the UK and the USA tend to decrease job performance and increase turnover following a breach in comparison to those who are from high collectivist societies. Therefore, we recommend that managers who deal with an employee who is from low collectivist societies should adopt more strategies such as by enhancing job autonomy through job redesigning or rotating to enhance job performance and reduce turnover following breaches. Managers may consider group-based incentives and rewards in high-collectivist societies to maintain employee job performance following breaches.

Moreover, our findings suggest that performance orientation practices moderated breach-related work outcomes. People who are exposed to low-performance orientation practices of the society such as employees in Argentina will respond more negatively to PCB concerning $\mathrm{OCB}$, such that they are less willing to perform extra-role behaviors. Therefore, knowing individual employees in low-performance societies are less interested in job performance but more interested in relationships, managers could improve relationships with employees to enhance their performance following breaches. This can be achieved by promoting communication and helping employees to feel valued and inspiring employees by 
developing and maintaining effective informal communication channels through various levels of employees within the organizations to maintain smooth work relationships. On the contrary, employees in the USA and Europe will respond less negatively to PCB concerning OCB, and we recommend managers consider reforming programs that emphasize organizational mechanisms to improve the performance management systems and rewarding practices to maintain employee performance following breaches.

Power-distance practices moderated the relationship between $\mathrm{PCB}$ and in-role performance such that people who live-in high-power distance countries such as China are more tolerant to breach (Mathew and Taylor, 2019). In low power distance countries such as the Netherlands and the United Kingdom, managers should take extra strategies to enhance job performance and reduce turnover, and this may be achieved by creating a participatory decision-making process within the organizations. Moreover, future society practices moderated the relationship between $\mathrm{PCB}$ and in-role performance, turnover intention, and actual turnover. Based on our findings, we recommend that managers could take extra steps to help employees to plan and invest in their career within the organizations and also to embrace future-oriented decisions of their employees to retain them, particularly when managing employees from high future society countries such as Canada.

Our findings showed no impact on breach-related work outcomes of society's uncertainty avoidance. This is surprising as this is opposed to what we expected but the findings can be explained. For example, it may be that employees who live in low uncertainty societies did not experience the uncertainty of finding an alternative job if they underperformed or left voluntary the existing job due to having other employment opportunities in their countries. Regarding gender-egalitarian societies, our findings showed that gender egalitarianism practices moderated the relationship between $\mathrm{PCB}$ and in-role performance and turnover intention. In high gender-egalitarian societies, more effort needs to develop national policies 
to enhance employee performance and reduce turnover through ongoing training, reward management system, and an effective communicational channel between the managers and employees across all levels. In contrast, in low gender-egalitarian societies, policies related to recruitment, training, and performance management could be developed to recognize and promote gender role differences at work.

In conclusion, we recommend policymakers to use these results to guide them in adopting a strategic perspective to manage breach-related employee performance and turnover. We recommend implementing national reforms that concern the dominant national culture (based on GLOBE's scores) in more affected countries. Moreover, we recommend managers to introduce HRM policies to suit national cultural practices based on geographic areas or clusters as identified in the GLOBE (House et al., 2004). To enhance employee performance and reduce turnover following breaches, managers should prioritize developing strategies to promote high-performance management system within their organizations and among employees in the GLOBE European cultures while prioritizing to enhance employee relations through establishing a sense of team when organizing work and rewarding teams in employees who belong to the GLOBE Asian clusters. It may be beneficial to include more feedback mechanisms in low power distance and high gender-egalitarian countries that belong to the GLOBE European clusters. However, at the moment, we have only a limited number of original studies reporting the findings related to the GLOBE culture clusters or geographic areas beyond Europe and Asia. Thus, there is a need for future researchers to address this limitation. 


\section{References}

Albert, B. (1998), "Health promotion from the perspective of social cognitive theory", Psychology \& Health, Vol. 13 No. 4, pp. 623-649.

Aldossari, M. (2016), "National and organisational culture as influences on the psychological contract: a Saudi Arabia comparative study", available at:

https://www.research.ed.ac.uk/portal/files/29545533/Abstract forThe_Bi_Annual_Psyc hological_Contract_Small_Group_Conference 2_.pdf/ (accessed 15 December 2019).

Allen, D.G., Weeks, K.P. and Moffitt, K.R. (2005), “Turnover intentions and voluntary turnover: the moderating roles of self-monitoring, locus of control, proactive personality, and risk aversion”, Journal of Applied Psychology, Vol. 90 No. 5, pp. 980990.

Ali, M., and Brooks, L. (2008), "Culture and IS: National cultural dimensions within IS discipline, available at: http://bura.brunel.ac.uk/handle/2438/2656/ (accessed 12 August $\underline{2019)}$.

Alutto, J. (2002), “Culture, levels of analysis, and cultural transition”, Yammarino, F. and Dansereau, F. (Ed.), The Many Faces of Multi-Level Issues, JAI Press., San Francisco, pp. 321-326.

Arshad, R. (2016), "Psychological contract violation and turnover intention: do cultural values matter?”, Journal of Managerial Psychology, Vol. 31 No. 1, pp. 251-264.

Aspinwall, L.G. (2005), “The psychology of future-oriented thinking: from achievement to proactive coping, adaptation, and aging”, Vol. 29 No. 4, pp. 203-235.

Aspinwall, L. and Leaf, S. (2002), "In search of the unique aspects of hope: pinning our hopes on positive emotions, future-oriented thinking, hard times, and other people", Psychological Inquiry, Vol. 13 No. 4, pp. 276-288. 
Autio, E., Pathak, S. and Wennberg, K. (2013), "Consequences of cultural practices for entrepreneurial behaviors”, Journal of International Business Studies, Vol. 44. pp. 334362.

Avital, M. (2000), "Dealing with time in social inquiry: a tension between method and lived experience", Organizational Science, Vol. 11 No. 2, pp. 665-673.

Azim, A., Azim, M., Ahmad, A., Omar, Z., Abu., and Silong, D. (2015), “Does Psychological contract on work-family benefits improve employee commitment?", Asian Social Science, Vol. 11, available at: 10.5539/ass.v11n13p71 (accessed 15 Julu 2020).

Bal, P.M., De Lange, A.H., Jansen, P.G.W. and Van Der Velde, M.E.G. (2008), "Psychological contract breach and job attitudes: a meta-analysis of age as a moderator", Journal of Vocational Behaviour, Vol. 72 No.1, pp. 143-158.

Bal, P.M. and Dóci, E. (2018), "Neoliberal ideology in work and organizational psychology", European Journal of Work and Organizational Psychology, Vol. 27 No. 5, pp. 536-548.

Bandura, A. (2002), "Social cognitive theory in cultural context", Applied Psychology: An International Review, Vol. 51 No. 2, pp. 269-290.

Bauer, T.N., Bodner, T., Erdogan, B., Truxillo, D.M. and Tucker, J.S. (2007), "Newcomer adjustment during organizational socialization: a meta-analytic review of antecedents, outcomes, and methods", Journal of Applied Psychology, Vol. 92 No. 3, pp. 707-721.

Bandura, A. (1986), Social Foundations of Thought and Action: A Social Cognitive Theory, Prentice-Hall, Englewood Cliffs, NJ.

Bandura, A. (1998), "Health promotion from the perspective of social cognitive theory", Psychology \& Health, Vol. 13 No. 4, pp. 623-649.

Behery, M., Abdallah, S., Parakandi, M. and Kukunuru, S. (2016), "Psychological contracts and intention to leave with mediation effect of organizational commitment and employee 
PCB AND CULTURE

satisfaction at times of recession", Review of International Business and Strategy, Vol. 26 No. 2, pp. 184-203.

Betz, M., O'Connell, L. and Shepard, J.M. (1989), "Gender difference in proclivity for unethical behavior", Journal of Business Ethics, Vol. 8, pp. 321-4.

Blau, P.M. (1964), Exchange and Power in Social Life, Routledge, London \& New York.

Borman, W.C. and Motowidlo, S.J. (1997), “Task performance and contextual performance: the meaning for personnel selection research", Human Performance, Vol. 10 No. 2, pp. 99-109.

Burda, M., Hamermesh, D.S. and Weil, P. (2007), “Total work, gender, and social norms”, Journal of Population Economics, Vol. 26, pp. 239-261.

Burda, M., Hamermesh, D.S. and Weil, P. (2013), "Total work and gender: facts and possible explanations", Journal of Population Economics, Vol. 26, pp. 239-261.

Carl, D., Gupta, V. and Javidan, M. (2004), "Power distance", House, R.J., Hanges, P.J., Javidan, M., Dorfman, P.W. and Gupta, V. (Eds.), Culture, Leadership, and Organizations: The GLOBE Study of 62 Societies, Sage, Thousand Oaks, CA, pp. 437512.

Camgoz, S.M., Ekmekci, O.T., Karapinar, P.B. and Guler, B.K. (2016), "Job insecurity and turnover intentions: gender differences and the mediating role of work engagement", Sex Roles, Vol. 75 No. 11, pp. 583-598.

Chao, J.M.C., Cheung, F.Y.L. and Wu, A.M.S. (2011), "Psychological contract breach and counterproductive workplace behaviors: testing moderating effect of attribution style and power distance", The International Journal of Human Resource Management, Vol. 22 No. 4, pp. 763-777.

Chen, Z.X., Tsui, A.S. and Zhong, L. (2007), "Reactions to psychological contract breach: a dual perspective", Journal of Organizational Behaviour, Vol. 29 No. 5, pp. 527-548. 
Chiu, C.Y., Gelfand, M., Yamagishi,T., Shteynberg, G. and Wan, C. (2010), "Intersubjective culture: the role of intersubjective perceptions in cross-cultural research", Perspectives on Psychological Science, Vol. 5 No. 4, pp. 482-493.

Cislaghi, B. and Heise, L. (2018), "Theory and practice of social norms interventions: eight common pitfalls", Globalization and Health, Vol.14 No. 83, pp. 93-88.

Clinton, M.E. and Guest, D.E. (2013), "Psychological contract breach and voluntary turnover: testing a multiple mediation model", Journal of Occupational and Organizational Psychology, Vol. 87 No. 1, pp. 200-207.

Cohen, A.B. and Hill, P.C. (2007), "Religion as culture: religious individualism and collectivism among American Catholics, Jews, and Protestants”, Journal of Personality, Vol. 75 No. 4, pp. 709-742.

Cohen, A.B., Wu, M.S. and Miller, J. (2016), "Religion and culture: individualism and collectivism in the East and West", Journal of Cross-Cultural Psychology, Vol. 47 No. 9, pp. 1236-1249.

Conway, N. and Briner, R.B. (2005), Understanding Psychological Contracts at Work: A Critical Evaluation of Theory and Research, Oxford University Press, Oxford.

Coyle-Shapiro, J.A. (2002), “A psychological contract perspective on organizational citizenship behaviour", Journal of Organizational Behaviour, Vol. 23 No. 8, pp. 927 946.

Cruz, K.S., Zagenczyk, T.J., Scott, K., Thoroughgood, C. and Cheung, J. (2018), “Perceptions of psychological contract breach and perceptions of co-worker exclusion: The moderating effects of collectivism and individualism", Occupational Health Science, Vol. 2, pp. 233-245. 
PCB AND CULTURE

Cullen, J.B., Parboteeah, K.P. and Hoegl, M. (2004), “Cross-national differences in managers' willingness to justify ethically suspect behaviors", Academy of Management Journal, Vol. 47, No. 3, pp. 411-421.

Czarnecka, B., Brennan, R. and Keles, S. (2018), “Cultural meaning, advertising, and national culture: a four-country study”, Journal of Global Marketing, Vol. 31 No. 1, pp. 1-14.

Daniels, M.A. and Greguras, G.J. (2014), “Exploring the nature of power distance: implications for micro- and macro-level theories, processes, and outcomes", Journal of Management, Vol. 40 No. 5, pp. 1202-1229.

Daumiller, M. and Janke, S. (2019), "Effects of performance goals and social norms on academic dishonesty in a test", British Journal of Educational Psychology, pp. 1-23.

De Hauw, S. and De Vos, A. (2010), Millennials' career perspective and psychological contract expectations: does the recession lead to lowered expectations?" Journal of Business and Psychology, Vol. 25 No. 2, pp. 293-302.

Doellgast, V. and Marsden, D. (2018), “Institutions as constraints and resources: Explaining cross-national divergence in performance management”, Human Resource Management Journal, Vol. 29 No. 2, pp. 199-216.

Earley, P.C. and Erez, M. (1997), The Transplanted Executive, Oxford University Press, New York, NY.

Edwards, G., Chikhouni, A. and Molz, R. (2019), "Job satisfaction in the global MNE: does distance matter?", Cross Cultural \& Strategic Management, Vol. 26 No. 3, pp. 337-362.

Emrich, C., Denmark, F. and Den Hartog, D. (2004), “Cross-cultural differences in gender egalitarianism: Implications for societies, organizations, and leaders", House, R., Hanges, P., Javidan, M., Dorfman, P. and Gupta, V. (Ed.), Culture, Leadership, and Organizations : The GLOBE Study of 62 Societies, Sage, New York, NY, pp. 343-394. 
Fisher, R. (2009), "Where is culture in cross-cultural research? an outline of a multi-level research process for measuring culture as a shared meaning system", International Journal of Cross-Cultural Management, Vol. 9 No. 1, pp. 25-49.

Fischer, R., Ferreira, M.C., Assmar, E.M.L., Redford, P., and Harb, C. (2005), “Organizational behaviour across cultures: theoretical and methodological issues for developing multilevel frameworks involving culture", International Journal of Cross-Cultural Management, Vol. 5 No.1, pp. 27-48.

Fischer, R. and Mansell, A. (2009), “Commitment across cultures: a meta-analytical approach”. Journal of International Business Studies, Vol. 40, No. 8, pp. 1339-1358.

Fischer, R. and Schwartz, S. (2011), "Whence differences in value priorities? individual, cultural, or artifactual sources”, Journal of Cross-cultural Psychology, Vol. 42 No. 8, pp. 1127-1144.

Fiske, S.T. and Taylor, S.E. (1984), Social Cognition, Addison-Wesley, Reading.

Fortin, N.M. (2005), "Gender role attitudes and the labour-market outcomes of women across OECD countries”, Oxford Review of Economic Policy, Vol. 21 No. 3, pp. 416-438.

Frese, M. (2015), "Cultural practices, norms and values", Journal of Cross-Cultural Psychology, Vol. 46 No. 10, pp. 1327-1330.

Geyskens, I., Steenkamp, J.E.M. and Kumar, N. (2006), "Make, buy, or ally: a transaction cost theory meta-analysis", Academy of Management Journal, Vol. 49 No. 3, pp. 519-543.

Ghosh, A. (2011), "Power distance in organizational contexts-a review of collectivist cultures”, Indian Journal of Industrial Relations, Vol. 47 No.1, pp. 89-101.

Grove, C.N. (2005), Introduction to the GLOBE research project on leadership worldwide, available at: https://www.grovewell.com/wp-content/uploads/pub-GLOBE-intro.pdf/ (accessed 12 November 2019). 
PCB AND CULTURE

Gupta, V. (2011), “Cultural basis of high-performance organizations”, International Journal of Commerce and Management, Vol. 21 No. 3, pp. 221-240.

Gul, H., Usman, M., Liu, Y., Rehman, Z. and Jebran, K. (2018), "Does the effect of power distance moderate the relation between person environment fit and job satisfaction leading to job performance? evidence from Afghanistan and Pakistan”, Future Business Journal, Vol. 4 No. 1, pp. 68-83.

Harvey, P. (2013), The Selfless Mind: Personality, Consciousness and Nirvana in Early Buddhism, Routledge, New York.

Haybatatollahi, S.M. and Gyekye, S.A. (2015). "Organizational citizenship behaviour: a crosscultural comparative study on Ghanaian and Finnish Industrial workers", Scandinavian journal of Organizational Psychology, Vol. 7 No. 1, pp. 19-32.

Heales, J., Cockcroft, S., Raduescu, C. (2004), "The influence of national culture on the level and outcome of IS development decisions", Journal of Global Information Technology Management, Vol. 7 No. 4, pp. 3-28.

Herriot, P. and Stickland, R. (1996), "Career management: The issues of the millennium", European Journal of Work and Organizational Psychology, Vol. 5 No. 4, pp. $465-470$.

Hodgson, D. (2011), The Mind Matters: Consciousness and Choice in a Quantum World, Oxford Scholarship Online, Oxford.

Hofstede, G. (1980), Culture's Consequences: International Differences in Work-related Values. Sage, Beverly Hills, CA.

Hofstede, G. (1997), Cultures and Organizations: Software of the Mind. McGraw-Hill, London.

Hofstede, G. (2001), Culture's Consequences: Comparing Values, Behaviors, Institutions and Organizations Across Nations, Sage, Thousand Oaks, CA. 
House, R.J., Hanges, P.J., Javidan, M., Dorfman, P.W. and Vipin, G. (2004), Culture, Leadership, and Organizations: The GLOBE Study of 62 Societies, Sage, Thousand Oaks, CA.

Hunter, J.E. and Schmidt, F.L. (2004), Methods of Meta-analysis: Correcting Error and Bias in Research Findings, Sage, Thousand Oaks, CA.

Hwang, Y. (2009), "The impact of uncertainty avoidance, social norms and innovativeness on trust and ease of use in electronic customer relationship management”, Electron Markets, Vol. 19, pp. 89-98.

Jackofsky, E. (1987), “Turnover and performance: an integrated process model”, Academy of Management Review, Vol. 9 No. 1, pp. 73-84.

Jaramillo, F., Mulki, J.P. and Marshall, G.W. (2005), “A meta-analysis of the relationship between organizational commitment and salesperson job performance: 25 years of research", Journal of Businesses Research, Vol. 58 No. 6, pp. 705-714.

Javidan, M., House, R.J., Dorfman, P.W., Hanges, P.J. and Sully de Luque, M. (2006), "Conceptualizing and measuring cultures and their consequences: a comparative review of GLOBE's and Hofstede's approaches", Journal of International Business Studies, Vol. 37 No. 6, pp. 897-914.

Jayaweera, A.T., Bal, M., Chudzikowski, K. and De Jong, S. (2020) (Accepted/In press), “The impact of economic factors on the relationships between psychological contract breach and work outcomes: a meta-analysis", Employee Relations.

Johns, G. (2018), "Advances in the treatment of context in organizational research", Annual Review of Organizational Psychology and Organizational Behaviour, Vol. 5 No. 5, pp. 21-46.

Johnson, E.C. and Meade, A.W. (2010), "A multi-level investigation of overall job performance ratings", Paper presented at the 25th Annual Meeting of the Society for 
PCB AND CULTURE

Industrial and Organizational Psychology, 28 March 2010, Atlanta, GA, available at: https://www.scribd.com/doc/301007656/A-Multi-Level-Investigation-of-Overall-JobPerformance-Ratings (accessed 20 February 2020)

Kalleberg, A.L. (2009), "Precarious work, insecure workers: employment relations in transition”. American Sociology Review, Vol. 74 No. 1, pp. 1-22.

Khatri, N. (2009). "Consequences of power distance orientation in organisations", Vision: The Journal of Business Perspective, Vol. 13 No.1, pp. 1-9.

Kickul, J., Lester, S.W. and Belgio, E. (2004), "Attitudinal and behavioral outcomes of psychological contract breach: a cross cultural comparison of the United States and Hong Kong Chinese", International Journal of Cross-Cultural Management, Vol. 4 No. 2, pp. $229-252$.

Kiewitz, C., Restubog, S., Zagenczyk, T. and Hochwarter, W. (2009), “The interactive effects of psychological contract breach and organizational politics on perceived organizational support: evidence from two longitudinal studies, Journal of Management Studies, Vol. 46 , pp. $806-834$.

Kinias, Z., Kim, H.S., Hafenbrack, A.C. and Lee, J.J. (2014), "Standing out as a signal to selfishness: culture and devaluation of non-normative characteristics", Organizational Behaviour and Human Decision Process, Vol. 124 No. 2, pp. 190-203.

Kraimer, M.L., Wayne, S.J. and Jaworski, R.A. (2001), "Sources of support and expatriate performance: the mediating role of expatriate adjustment", Personnel Psychology, Vol. 54 No.1, pp. 71-99.

Krasnova, H., Veltri, N.F. and Günther, O. (2012), "Self-disclosure and privacy calculus on social networking sites: The role of culture", Business \& Information System Engineering, Vol. 4, pp. 127-135. 
Kucharska, W. and Bedford, D.A.D. (2019), “Knowledge sharing and organizational culture dimensions: Does job satisfaction matter?”, SSRN Electronic Journal, Vol. 17 No.1, pp. $1-18$.

Lelchook, A. and Sully de Luque, M. (2015), "Cross-Cultural Training in Industrial and Organizational Psychology", International Encyclopedia of the Social \& Behavioral Sciences, Vol. 2, pp. 334-341.

Levinson, H. (1965), "Reciprocation: the relationship between man and organization", Administrative Science Quarterly, Vol. 9, pp. 370-390.

Lim, N. (2016), “Cultural differences in emotion: differences in emotional arousal level between the East and the West", Integrative medicine research, Vol. 5 No. 2, pp. 105109.

Lu, C.S. and Lin, C.C. (2014), "Effects of national culture differences on job performance in container shipping: the moderating role of transformational leadership", Journal of Marine Science and Technology, Vol. 22 No.4, pp. 463-475.

Lucia-Casademunt, A.M., Cuéllar-Molina, D. and García-Cabrera, A.M. (2018), "The role of human resource practices and managers in the development of well-being: cultural differences in the changing workplace", Cross Cultural \& Strategic Management, Vol. 25 No. 4, pp. 716-740.

Luu, L., Beach, L. and Hattrup, K. (2010), “An investigation of country differences in the relationship between job satisfaction and turnover intentions", Applied Human resource Management Research, Vol. 12 No. 1, pp. 17-39.

Lyness, K.S. and Judiesch, M.K. (2014), “Gender egalitarianism and work-life balance for managers: multisource perspectives in 36 countries", Applied Psychology: An International Review, Vol. 63 No.1, pp. 96-129. 
Maertz, C.P. (2004), "Five antecedents neglected in employee turnover models", In Griffeth, R. Hom, P. (Ed.), Innovative Theory and Empirical Research on Employee Turnover, Greenwich, pp. 105-152.

Markus, H. and Kitayama, S. (1991), "Culture and the self: implications for cognition, emotion, and motivation", Psychology of Review, Vol. 98, pp. 224-253.

Mathew, S. and Taylor, G. (2019), "Power distance in India: paternalism, religion and caste: some issues surrounding the implementation of lean production techniques", Cross Cultural \& Strategic Management, Vol. 26 No. 1, pp. 2-23.

Messner, S.F. and Rosenfeld, F. (2001), Crime and the American Dream, third ed. Belmont, CA, Wadsworth.

Morrison, E.W. and Robinson, S.L. (1997), "When employees feel betrayed: a model of how psychological contract violation develops", The Academy of Management Review, Vol. 22, pp. 226-256.

Mu Y., Kitayama S., Han S. and Gelfand M.J. (2015), "How culture gets embrained: cultural differences in event-related potentials of social norm violations", Proceedings of the National Academy of Sciences USA, Vol. 112, pp. 15348-15353.

Nadeem, S. and Sully de Luque, M. (2017), "Developing an Understanding of the HR Complexities in Pakistan with a GLOBE Cultural Lens", Journal of Management and Organization, available at:10.1017/jmo.2017.79 (accessed 12 March 2020).

Nanda, R. and Sorensen, J.B. (2010), “Workplace peers and entrepreneurship”, Management Science, Vol. 56 No. 7, pp. 1116-1126.

Newman, A. and Sheikh, A.Z. (2012), "Organizational rewards and employee commitment: a Chinese study”, Journal of Managerial Psychology, Vol. 27 No. 1, pp. 71-80. 
Newburry, W. and Yakova, N. (2006), "Standardization preferences: a function of national culture, work independence and local embeddedness, Journal of International Business Studies, Vol. 37, pp. 44-60.

Orpen, C. (1995). "The effect of socialization tactics on career success and satisfaction: a longitudinal study", International Journal of Commerce and Management, Vol. 5, pp. 33.

Oyserman, D., Coon, H.M. and Kemmelmeier, M. (2002), "Rethinking individualism and collectivism: evaluation of theoretical assumptions and meta-analyses", Psychology Bulletin, Vol. 128 No. 1, pp. 3-72.

Ozorio, B., Lam, D. and Fong, H.N. (2010), “The influence of individualism and uncertainty avoidance on per capita gambling turnover", International Gambling Studies, Vol. 10 No. 3, pp. 221-238.

Palthe, J. (2014), “Cross-Level Cultural Congruence: implications for managing diversity in multinational corporations", Journal of Diversity Management, Vol. 9, pp. 51-55.

Papademetriou, C. and Masouras, A. (2014), "National culture underpins individual behaviour and work-related-values: the importance of nationality", Review of Decentralization Local Government and Regional Development, pp. 77-84.

Parboteeah, K.P., Bronson, J.W. and Cullen, J.B. (2005), "Does national culture affect willingness to justify ethically suspect behaviors? a focus on the GLOBE national culture scheme", International Journal of Cross-cultural Management, Vol. 5 No. 2, pp. 123138.

Park, T.Y. and Shaw, J.D. (2013). "Turnover rates and organizational performance: a metaanalysis", Journal of Applied Psychology, Vol. 98 No. 2, pp. 268-309. 
Peretz, H. and Fried, Y. (2012), "National cultures, performance appraisal practices, and organizational absenteeism and turnover: a study across 21 countries”, Journal of Applied Psychology, Vol. 97 No. 2, pp. 448-459.

Peretz, H., Fried, Y. and Levi, A. (2017), "Flexible work arrangements, national culture, organisational characteristics, and organisational outcomes: a study across 21 countries", Human Resource Management Journal, Vol. 28, pp. 182-200.

Pettigrew, A.M. (1997), "What is a processual analysis?", Scandinavian Journal of Management, Vol. 3, pp. 337-348.

Pudelko, M. (2006), “A comparison of HRM systems in the USA, Japan and Germany in their socio-economic context”, Human Resource Management Journal, Vol. 16, pp. 123-153.

Qian, J., Lin, X., Han, Z., Tian, B., Chen, G. and Wang, H. (2015), “The impact of future time orientation on employees' feedback-seeking behavior from supervisors and co-workers: the mediating role of psychological ownership", Journal of Management and Organizational Behaviour, Vol. 21, pp. 1-14.

Rabl, T., Jayasinghe, M., Gerhart, B. and Kühlmann, T.M. (2014), “A meta-analysis of country differences in the high-performance work system-business performance relationship: the roles of national culture and managerial discretion", Journal of Applied Psychology, Vol. 99 No. 6, pp. 1011-1041.

Rafiei, S. and Pourreza, A. (2013), “The moderating role of power distance on the relationship between employee participation and outcome variables", International Journal of Health Policy and Management, Vol. 1, pp. 79-83.

Rahman, U.U., Rehman, C.A., Imran, M.K. and Aslam, U. (2017), "Does team orientation matter? linking work engagement and relational psychological contract with performance”, Journal of Management Development, Vol. 36 No. 9, pp. 1102-1113. 
Rao, A.N. and Pearce, J.L. (2016), "Should management practice adapt to cultural values? the evidence against power distance adaptation", Cross Cultural \& Strategic Management, Vol. 23 No. 2.

Rispens, S. and Demerouti, E. (2016), “Conflict at work, negative emotions, and performance: a diary study", Negotiation and Conflict Management Research, Vol. 9 No. 2, pp. 103119.

Rosner, J.B. (1990), “Ways women lead”, Harvard Business Review, pp. 95 - 105.

Rousseau, D.M. (1989), "Psychological and implied contracts in organizations", Employee Responsibilities and Rights Journal, Vol. 2, pp. 121-139.

Rousseau, D.M. and Schalk, R., (2000), Psychological Contracts in Employment: Crossnational Perspectives, Thousand Oaks, Sage, CA.

Sadowski, E. and Schranger, S. (2016), “Achieving career satisfaction: personal goal setting and prioritizing for the clinician educator", Journal of Graduate Medical Education, Vol. 8, pp. 494-497.

Salamin, A., \& Hom, P.W. (2005), "In search of the elusive u-shaped performance-turnover relationship: are high performing swiss bankers more liable to quit?”, Journal of Applied Psychology, Vol. 90 No. 6, pp. 1204-1216.

Sanchez-Burks, J., Nisbett, R.E. and Ybarra, O. (2000), “Cultural styles, relational schemas and prejudice against outgroups", Journal of Personality and Social Psychology, Vol. 79 Vol. 2, pp. 174-189.

Scherer K.R. (2009), “Emotions are emergent processes: they require a dynamic computational architecture”, Series B, Biological sciences, Vol. 364, pp. 3459-3474.

Schyns, B., Torka, N. and Gössling, T. (2007), "Turnover intention and preparedness for change”, Career Development International, Vol. 12 No. 7, pp. 660-679. 
PCB AND CULTURE

Smith, P. (2006). "When elephants fight, the grass gets trampled: the GLOBE and Hofstede projects”, Journal of International Business Studies, Vol. 37 No.6, pp. 915-21.

Stamkou, E., Van Kleef, G.A., Homan, A.C., Gelfand, M.J., Van der Vijver, F.J.R., Van Egmond, M. C., Boer, D., Phiri, N., Ayub, N., Kinias, Zoe., Cantaero, K., Triester, D.E.,

Stajkovic, A.D. and Luthans, F. (1997), "Business ethics across cultures: a social cognitive model”, Journal of World Business, Vol. 32 No. 1, pp. 17-34.

Sturman, M.C., Shao, L. and Katz, J.H. (2012), "The effect of culture on the curvilinear relationship between performance and turnover", Journal of Applied Psychology, Vol. 97 No.1, pp. 46-62.

Taras, V., Steel, P. and Kirkman, B.L. (2011), “Three decades of research on national culture in the workplace: do the differences still make a difference?", Organizational Dynamics, Vol. 40 No. 3, pp. 189- 198.

Thomas, D.C., Au, K. and Ravlin, E.C. (2003), "Cultural variation and the psychological contract”, Journal of Organizational Behaviour, Vol. 24, pp. 451-471.

Thomas, D.C., Fitzsimmons, S.R., Ravlin, E.C., Au, K.Y., Ekelund, B.Z. and Barzantny, C. (2010), "Psychological contracts across cultures", Organizational Studies, Vol. 31, pp. $1437-1458$.

Thomas, D.C., Ravlin, E.C., Liao, Y., Morrell, D.L. and Au, K. (2016), “Collectivist values, exchange ideology and psychological contract preference”, Management International Review, Vol. 56 No. 2, pp. 255-281.

Trommsdorff, G. (1983), "Future orientation and socialization", International Journal of Psychology, Vol. 18, No. 5, pp. 381-406.

Turner, J. and Stets, J. (2005), "The Sociology of Emotions", pp. 1-347, available at: 10.1017/CBO9780511819612 (accessed 02 April 2010). 
Van de Vijver, F.R., Van Hemert, D.A. and Poortinga, Y.H. (2008), Multilevel Analysis of Individuals and Cultures, first ed, Psychology Press, New York, NY.

Van Hemert, D.A., Van de Vijver, F.J.R. and Poortinga, Y.H. (2008), "Multilevel models of individuals and cultures: current state and outlook", Van de Vijver, F.J.R., Van Hemert, D.A. and Poortinga, Y.H. (Ed.), Multilevel Analysis of Individuals and Cultures, Taylor \& Francis Group/Lawrence Erlbaum Associates, NY, pp. 413-429.

Vantilborgh, T., Bal, P., Bingham, J. and Lambert, L. (2013), "Diverse reactions to psychological contract breach and fulfilment: A cross cultural study", available at: 10.5465/AMBPP.2013.13441abstract (accessed 20 August 2020).

Varela, O., Salgado, E. and Lasio, M. (2010), “The meaning of the job performance in collectivistic and high-power distance culture, evidence from three Latin American countries", Cross Cultural Management, Vol. 17 No. 4, pp. 407-426.

Vora, D., Martin, L., Fitzsimmons, S.R., Pekerti, A.A., Lakshman, C. and Raheem,

S. (2018), "Multiculturalism within individuals: a review, critique, and agenda

for future research", Journal of International Business Studies, Vol. 50, pp. 499-524.

Westwood, R., Sparrow, P. and Leung, A. (2001), "Challenges to the psychological contract in Hong Kong”, International Journal of Human Resource Management, Vol. 12, No. 4, pp. $621-651$.

Wilson, T. and Gilbert, D. (2003), "Making sense: the causes of emotional evanescence”, The Psychology of Economic Decisions, Vol.1. No. 4, pp. 230-238.

Wong, K.F.E., Cheng, C. (2019), “The turnover intention-behaviour link: a culture-moderated meta-analysis", Journal of Managerial Studies, available at: https://doi.org/10.1111/joms.12520/ (accessed on 20 January 2020).

Zagenczyk, T.J., Cruz, K.S., Cheung, J.H., Scott, K.L., Kiewitz, C. and Galloway, Bret. (2015), "The moderating effect of power distance on employee responses to psychological 
contract breach”, European Journal of Work and Organizational Psychology, Vol. 24, No. 6, pp. 853-865.

Zhao, H., Wayne, S.J., Glibkowski, B.C. and Bravo, J. (2007), “The impact of psychological contract breach on work-related outcomes: a meta-analysis", Personnel Psychology, Vol. $60,647-680$. 
Table 1

Meta-analysis results of the main effects of psychological contract breach

\begin{tabular}{|c|c|c|c|c|c|c|c|c|c|c|c|}
\hline & & & & & & $\begin{array}{r}95 \\
\text { Confi } \\
\text { Inte }\end{array}$ & $\begin{array}{l}\text { \% } \\
\text { dence } \\
\text { rval }\end{array}$ & $\begin{array}{r}90 \\
\text { Cred } \\
\text { Inte }\end{array}$ & $\begin{array}{l}\text { \%o } \\
\text { ibility } \\
\text { rval }\end{array}$ & & \\
\hline Outcomes & $\boldsymbol{k}$ & $N$ & $r$ & $\rho$ & SDp & Lower & Upper & Lower & Upper & $\mathbf{Q}$ & $\begin{array}{r}\text { Fail } \\
\text { safe } \\
k\end{array}$ \\
\hline $\begin{array}{l}\text { In-role } \\
\text { performance }\end{array}$ & 34 & 8287 & -.21 & -.22 & .12 & -.26 & -.17 & -.42 & -.01 & 138 & 54 \\
\hline OCB & 33 & 20268 & -.22 & -.24 & .06 & -.24 & -.21 & .39 & -.06 & 211 & 54 \\
\hline $\begin{array}{l}\text { Turnover } \\
\text { intentions }\end{array}$ & 61 & 20753 & .32 & .34 & .18 & .29 & .39 & .02 & .70 & 947 & 79 \\
\hline $\begin{array}{l}\text { Actual } \\
\text { turnover }\end{array}$ & 6 & 6869 & .13 & .18 & .04 & .07 & .12 & .03 & .16 & 13 & 2 \\
\hline
\end{tabular}

Note: $k=$ number of studies; $N=$ number of observations; $r=$ mean uncorrected correlation; $\rho=$ true score correlation; $S D \rho=$ standard deviation of true score correlation; $Q=$ Cochran's $Q$ test; fail safe $K=$ the number of additional studies. 
Table 2

Meta-analytic results of the moderating roles of national cultural factors in the relationships between contract breach and job behaviors

\begin{tabular}{lllllll}
\hline Outcome & k & n & Coef. & s.e. & p & $\mathbf{R}^{2}$ \\
\hline
\end{tabular}

Institutional collectivism practices

$\begin{array}{lcccccc}\text { In-role performance } & 34 & 8632 & .37 & .01 & .02 & .14 \\ \text { Citizenship behaviour } & 33 & 20268 & .37 & .01 & .03 & .13 \\ \text { Turnover intention } & 61 & 20753 & -.29 & .01 & .02 & .08 \\ \text { Actual turnover } & 6 & 6879 & -.81 & .00 & n s & .65\end{array}$

Performance-oriented practices

$\begin{array}{lllllll}\text { In-role performance } & 34 & 8632 & .33 & .01 & \text { ns } & .10\end{array}$

$\begin{array}{lllllll}\text { Citizenship behaviour } & 33 & 20268 & .40 & .01 & .01 & .16\end{array}$

$\begin{array}{llllllll}\text { Turnover intention } & 61 & 20753 & -.03 & .01 & \text { ns } & .00\end{array}$

$\begin{array}{lllllll}\text { Actual turnover } & 6 & 6879 & .04 & .01 & n s & .00\end{array}$

Power distance practices

$\begin{array}{lllllll}\text { In-role performance } & 34 & 8632 & .37 & .01 & .03 & .13\end{array}$

$\begin{array}{lllllll}\text { Citizenship behaviour } & 33 & 20268 & .27 & .01 & n s & .07\end{array}$

$\begin{array}{llllllll}\text { Turnover intention } & 61 & 20753 & -.23 & .01 & n s & .05\end{array}$

$\begin{array}{lllllll}\text { Actual turnover } & 6 & 6879 & .59 & .00 & n s & .35\end{array}$

Future society practices

$\begin{array}{lllllll}\text { In-role performance } & 34 & 8632 & -.35 & .01 & .04 & .12\end{array}$

$\begin{array}{lllllll}\text { Citizenship behaviour } & 33 & 20268 & .08 & .01 & \text { ns } & .00\end{array}$

$\begin{array}{llllllll}\text { Turnover intention } & & 61 & 20753 & .27 & .01 & .03 & .07\end{array}$

$\begin{array}{lllllll}\text { Actual turnover } & 6 & 6879 & .90 & .00 & .01 & .81\end{array}$

Uncertainty avoidance practices

$\begin{array}{lllllll}\text { In-role performance } & 34 & 8632 & .18 & .01 & \text { ns } & .03\end{array}$

$\begin{array}{lllllll}\text { Citizenship behaviour } & 33 & 20268 & .24 & .01 & \text { ns } & .06\end{array}$

$\begin{array}{llllllll}\text { Turnover intention } & & 61 & 20753 & .08 & .01 & \text { ns } & .00\end{array}$

$\begin{array}{lllllll}\text { Actual turnover } & 6 & 6879 & -.49 & .00 & \text { ns } & .24\end{array}$

Gender egalitarianism practices

$\begin{array}{lllllll}\text { In-role performance } & 34 & 8632 & -.44 & .01 & .00 & .19\end{array}$

$\begin{array}{lllllll}\text { Citizenship behaviour } & 33 & 20268 & -.33 & .01 & \text { ns } & .11\end{array}$

$\begin{array}{llllllll}\text { Turnover intention } & & 61 & 20753 & .26 & .01 & .04 & .06\end{array}$

$\begin{array}{llllllll}\text { Actual turnover } & 6 & 6879 & .49 & .01 & \text { ns } & .24\end{array}$ 
Appendix A: Overview of Studies included in the Meta-Analysis

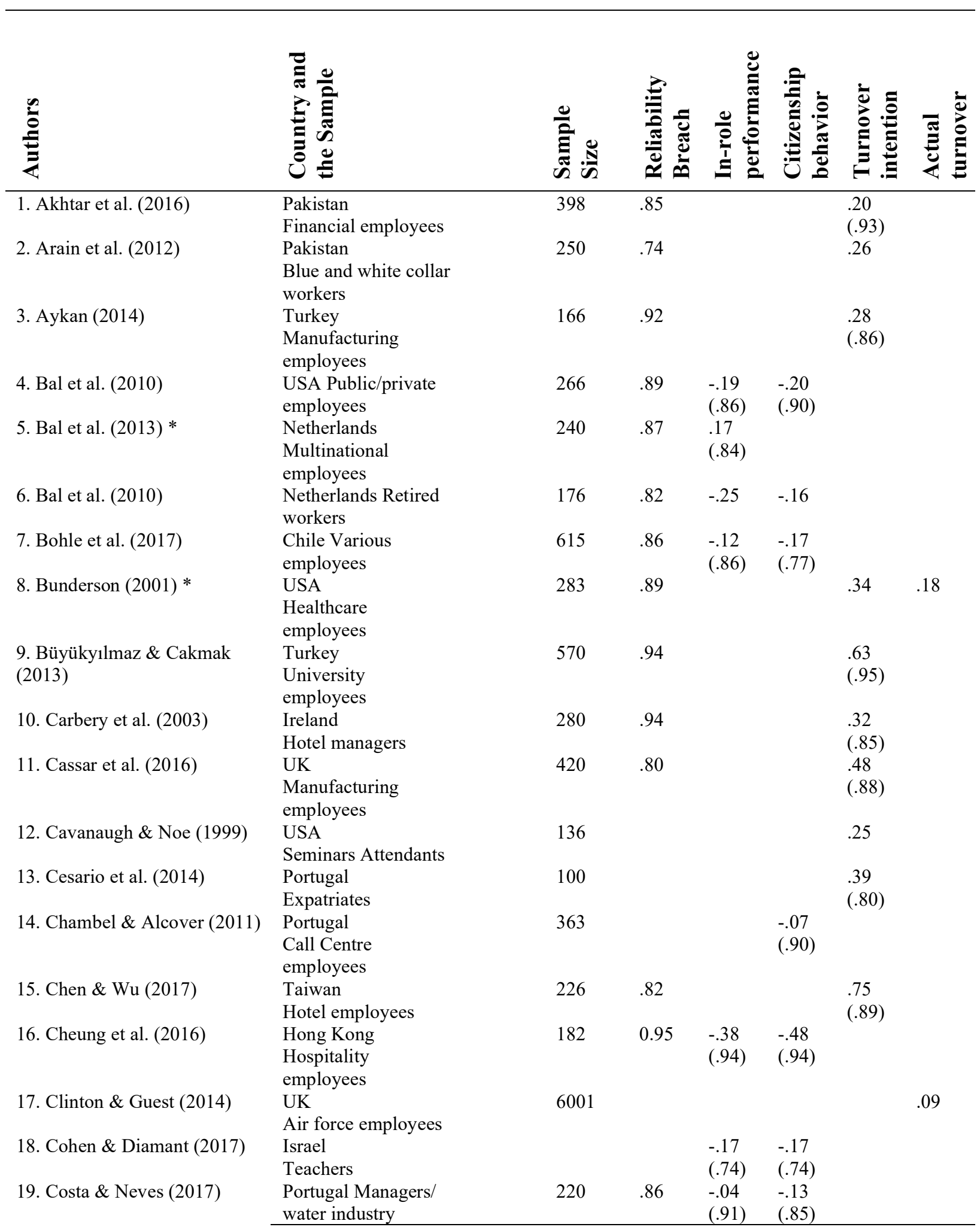




\begin{tabular}{|c|c|c|c|c|c|c|c|}
\hline $\begin{array}{l}\text { 20. Coyle-Shapiro \& Kessler } \\
(2000)\end{array}$ & $\begin{array}{l}\text { UK } \\
\text { Managers }\end{array}$ & 6953 & .87 & & $\begin{array}{l}-.17 \\
(.63)\end{array}$ & & \\
\hline $\begin{array}{l}\text { 21. Coyle-Shapiro \& Kessler } \\
\text { (2003) }\end{array}$ & $\begin{array}{l}\text { UK } \\
\text { Various employees }\end{array}$ & 5709 & .81 & & $\begin{array}{l}-.26 \\
(.74)\end{array}$ & & \\
\hline $\begin{array}{l}\text { 22. De Cuyper \& De Witte } \\
\text { (2006) }\end{array}$ & $\begin{array}{l}\text { Belgium } \\
\text { Hospital employees }\end{array}$ & 544 & .80 & $\begin{array}{l}-.24 \\
(.74)\end{array}$ & & & \\
\hline 23. De Jong et al. (2009) & $\begin{array}{l}\text { Netherlands Various } \\
\text { employees }\end{array}$ & 313 & .93 & & & $\begin{array}{l}.35 \\
(.78)\end{array}$ & \\
\hline 24. De Jong et al. (2009) & $\begin{array}{l}\text { Netherlands Various } \\
\text { employees }\end{array}$ & 523 & .96 & & & $\begin{array}{l}-.14 \\
(.79)\end{array}$ & \\
\hline 25. De Jong (2009) & $\begin{array}{l}\text { Netherlands Various } \\
\text { employees }\end{array}$ & 779 & & & & $\begin{array}{l}.01 \\
(.79)\end{array}$ & \\
\hline 26. Dulac et al. (2008) * & $\begin{array}{l}\text { Belgium Academic } \\
\text { staff }\end{array}$ & 152 & .95 & & & $\begin{array}{l}.57 \\
(.96)\end{array}$ & \\
\hline 27. Freese et al (1999)* & $\begin{array}{l}\text { Netherlands } \\
\text { Healthcare workers }\end{array}$ & 119 & .91 & & & $\begin{array}{l}.31 \\
(.88)\end{array}$ & \\
\hline 28. Freese \& Schalk (2008) & $\begin{array}{l}\text { Netherlands } \\
\text { Healthcare workers }\end{array}$ & 480 & .92 & & & .33 & \\
\hline 29. Gardner et al. (2015) * & $\begin{array}{l}\text { China } \\
\text { Various employees }\end{array}$ & 462 & .82 & $\begin{array}{l}-.02 \\
(.87)\end{array}$ & & $\begin{array}{l}.07 \\
(.79)\end{array}$ & \\
\hline 30. Granrose \& Baccili (2006) & $\begin{array}{l}\text { USA } \\
\text { Aerospace } \\
\text { employees }\end{array}$ & 145 & & & & $\begin{array}{l}.04 \\
(.88)\end{array}$ & \\
\hline $\begin{array}{l}\text { 31. Gregory et al. (2007) } \\
(2007)\end{array}$ & $\begin{array}{l}\text { Canada } \\
\text { Healthcare } \\
\text { employees }\end{array}$ & 343 & .70 & & & $\begin{array}{l}.38 \\
(.72)\end{array}$ & \\
\hline 32. Griep et al. (2016)* & $\begin{array}{l}\text { Belgium } \\
\text { Voluntary employees }\end{array}$ & 247 & & & -.16 & & \\
\hline 33. Guchait et al. (2015) & $\begin{array}{l}\text { India } \\
\text { Restaurant } \\
\text { employees }\end{array}$ & 289 & .90 & & & $\begin{array}{l}.38 \\
(.82)\end{array}$ & \\
\hline $\begin{array}{l}\text { 34. Guerrero \& Herrbach } \\
\text { (2005) }\end{array}$ & $\begin{array}{l}\text { France } \\
\text { Various employees }\end{array}$ & 217 & & & & .30 & \\
\hline $\begin{array}{l}\text { 35. Hartmann \& Rutherford } \\
\text { (2015) }\end{array}$ & $\begin{array}{l}\text { USA } \\
\text { Sales employees }\end{array}$ & 308 & .94 & $\begin{array}{l}-.12 \\
(.92)\end{array}$ & & $\begin{array}{l}.55 \\
(.69)\end{array}$ & \\
\hline 36. Henderson et al. (2008) & $\begin{array}{l}\text { USA } \\
\text { Industrial employees }\end{array}$ & 278 & .80 & $\begin{array}{l}-.17 \\
(.89)\end{array}$ & -.16 & & \\
\hline 37. Huiskamp \& Schalk (2002) & $\begin{array}{l}\text { Netherlands Various } \\
\text { employees }\end{array}$ & 1331 & .83 & & & $\begin{array}{l}.33 \\
(.86)\end{array}$ & \\
\hline 38. Jafri (2012) & $\begin{array}{l}\text { India } \\
\text { Bank executives }\end{array}$ & 90 & .84 & & $\begin{array}{l}-.15 \\
(.86)\end{array}$ & & \\
\hline $\begin{array}{l}\text { 39. Johnson \& O'Leary-Kelly } \\
\text { (2013) }\end{array}$ & $\begin{array}{l}\text { USA } \\
\text { Bank employees }\end{array}$ & 103 & .94 & $\begin{array}{l}-.33 \\
(.95)\end{array}$ & -.07 & & \\
\hline 40. Kraak et al. (2017) & $\begin{array}{l}\text { Netherlands Various } \\
\text { employees }\end{array}$ & 1066 & .95 & & & $\begin{array}{l}.39 \\
(.95)\end{array}$ & \\
\hline 41. Lapalme et al. (2011) & $\begin{array}{l}\text { Canada } \\
\text { Agency workers }\end{array}$ & 186 & .95 & & $\begin{array}{l}-.14 \\
(.91)\end{array}$ & & \\
\hline 42. Lapointe et al. (2013) & $\begin{array}{l}\text { Canada } \\
\text { Various employees }\end{array}$ & 224 & .95 & & & & $\begin{array}{l}.22 \\
(.90)\end{array}$ \\
\hline 43. Larwood et al. (1998) & $\begin{array}{l}\text { USA } \\
\text { Various employees }\end{array}$ & 257 & .75 & & & & $\begin{array}{l}.44 \\
(.85)\end{array}$ \\
\hline 44. Lee et al. (2014) & $\begin{array}{l}\text { USA Nonprofit } \\
\text { employees }\end{array}$ & 141 & .86 & $\begin{array}{l}-.20 \\
(.76)\end{array}$ & $\begin{array}{l}-.12 \\
(.72)\end{array}$ & & \\
\hline 45. Lee et al. (2011) & China & 136 & & & & .24 & \\
\hline
\end{tabular}




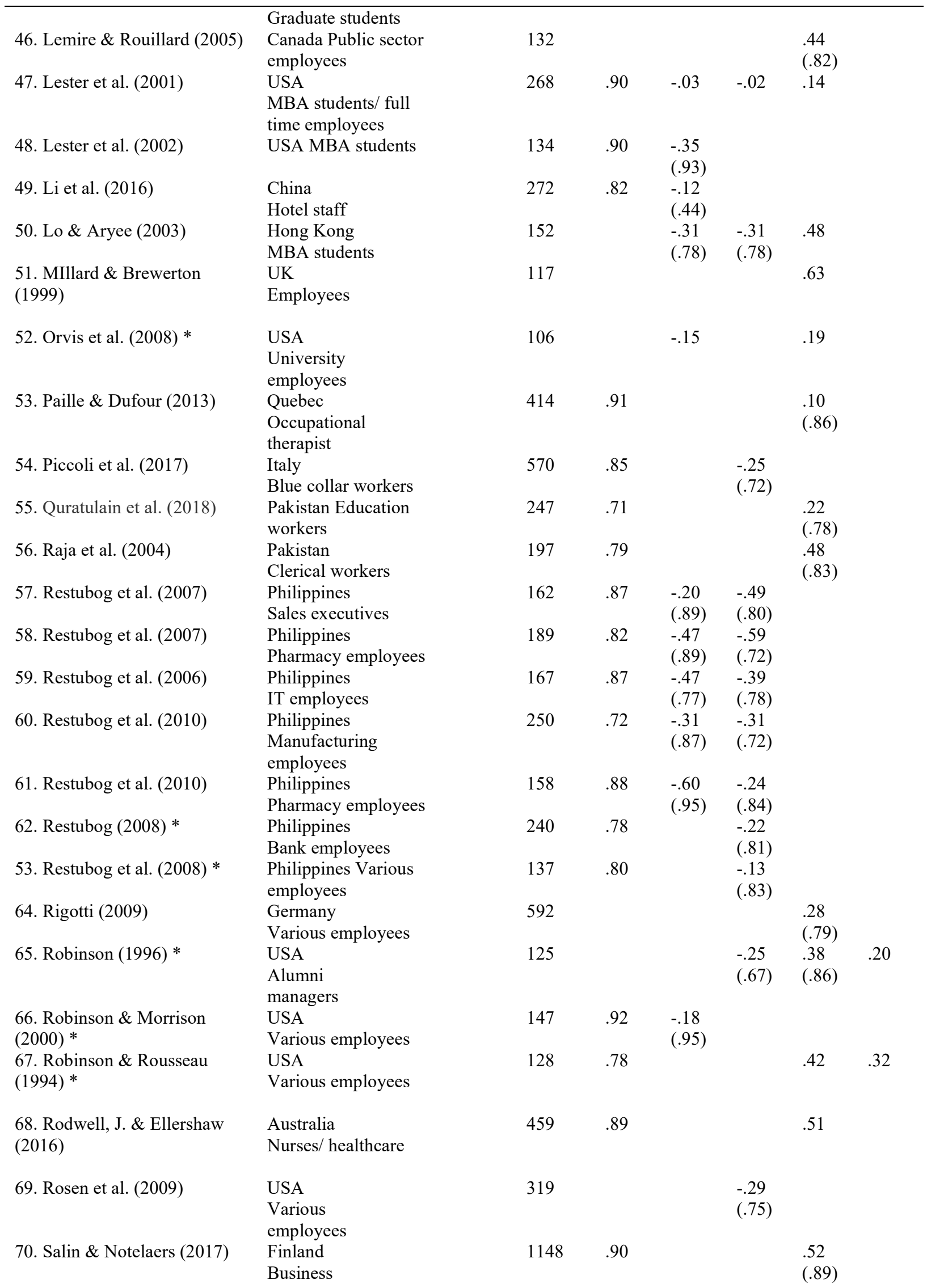




\begin{tabular}{|c|c|c|c|c|c|c|c|}
\hline \multirow{3}{*}{ 71. Schalk et al. (1995) } & Professionals & \multirow{3}{*}{338} & \multirow{3}{*}{.72} & & & \multirow[b]{2}{*}{.39} & \\
\hline & Netherlands & & & & & & \\
\hline & Various employees & & & & & \multicolumn{2}{|l|}{$(.87)$} \\
\hline \multirow{2}{*}{$\begin{array}{l}\text { 72. Shahnawaz, \& Goswami } \\
\text { (2011) }\end{array}$} & India & \multirow[t]{2}{*}{100} & \multirow[t]{2}{*}{.80} & & & \multicolumn{2}{|l|}{-.08} \\
\hline & $\begin{array}{l}\text { Private sector } \\
\text { managers }\end{array}$ & & & & & \multicolumn{2}{|l|}{$(.87)$} \\
\hline \multirow{2}{*}{$\begin{array}{l}\text { 73. Shahnawaz, \& Goswami } \\
\text { (2011) }\end{array}$} & India & 100 & .80 & & & \multirow{2}{*}{\multicolumn{2}{|c|}{$\begin{array}{l}.17 \\
(.87)\end{array}$}} \\
\hline & $\begin{array}{l}\text { Public sector } \\
\text { managers }\end{array}$ & & & & & & \\
\hline \multirow[t]{2}{*}{ 74. Shih et al. (2012) } & Taiwan & \multirow[t]{2}{*}{204} & \multirow[t]{2}{*}{.94} & -.19 & -.19 & & \\
\hline & $\begin{array}{l}\text { Theme park } \\
\text { employees }\end{array}$ & & & $(.90)$ & $(.90)$ & & \\
\hline \multirow[t]{2}{*}{ 75. Si et al. (2008) } & China & \multirow[t]{2}{*}{524} & & & & \multirow{2}{*}{\multicolumn{2}{|c|}{$\begin{array}{l}.32 \\
(84)\end{array}$}} \\
\hline & Various employees & & & & & & \\
\hline \multirow[t]{2}{*}{ 76. Steve \& Cheng (2007) } & Taiwan & \multirow[t]{2}{*}{135} & \multirow[t]{2}{*}{.88} & & & .42 & \\
\hline & Company employees & & & & & $(.82)$ & \\
\hline 77. Stoner et al. (2011) * & USA & 126 & .95 & & & .41 & \\
\hline & Various employees & & & & & $(.92)$ & \\
\hline 78. Stoner et al. (2010) & USA & 126 & & & & .46 & \\
\hline & Various employees & & & & & $(.92)$ & \\
\hline 79. Sturges et al. (2005) & UK & 151 & .91 & -.38 & & & .04 \\
\hline & Media employees & & & & & & \\
\hline 80. Suazo (2009) & USA & 196 & .89 & -.13 & & .35 & \\
\hline & $\begin{array}{l}\text { Managerial } \\
\text { employees }\end{array}$ & & & & & $(.87)$ & \\
\hline 81. Suazo et al. (2005) & USA & 234 & .88 & -.18 & -.28 & .57 & \\
\hline & Various employees & & & $(.87)$ & $(.93)$ & $(.76)$ & \\
\hline 82. Sutton \& Griffin (2004) * & Australia & 235 & & & & -.32 & \\
\hline & $\begin{array}{l}\text { Occupational therapy } \\
\text { students }\end{array}$ & & & & & $(.90)$ & \\
\hline 83. Takase et al. (2016) & Japan & 766 & .91 & & & .54 & \\
\hline & $\begin{array}{l}\text { Nurses and mid- } \\
\text { wives }\end{array}$ & & & & & $(.93)$ & \\
\hline 84. Tekleab et al. (2013) & USA & 106 & & -.07 & & -.15 & \\
\hline & $\begin{array}{l}\text { University } \\
\text { employees }\end{array}$ & & & $(.88)$ & & $(.97)$ & \\
\hline 85. Tekleab and Taylor (2003) & USA & 298 & .81 & -.14 & -.16 & .23 & \\
\hline & Various employees & & & $(.81)$ & $(.85)$ & $(.85)$ & \\
\hline 86. Tekleab et al. (2005) & USA & 191 & .83 & & & .14 & -.02 \\
\hline & $\begin{array}{l}\text { University } \\
\text { employees }\end{array}$ & & & & & $(.85)$ & \\
\hline 87. Turnley et al. (2003) & USA & 134 & .85 & -.38 & -.41 & & \\
\hline & Various employees & & & $(.93)$ & $(.85)$ & & \\
\hline 88. Turnley \& Feldman (1999) & USA & 781 & & & & .38 & \\
\hline & $\begin{array}{l}\text { Managerial } \\
\text { employees }\end{array}$ & & & & & $(.92)$ & \\
\hline 89. Turnley \& Feldman (2000) & USA & 804 & .83 & -.46 & -.46 & .48 & \\
\hline & $\begin{array}{l}\text { Managerial } \\
\text { employees }\end{array}$ & & & $(.81)$ & $(.81)$ & $(.93)$ & \\
\hline 90. Uen et al. (2009) & Taiwan & 127 & .80 & -.24 & -.21 & & \\
\hline & High-tech employees & & & $(.83)$ & $(.83)$ & & \\
\hline 91. Van den Heuvel et al. & Netherlands & 669 & & & & .38 & \\
\hline$(2017)$ & $\begin{array}{l}\text { Communication } \\
\text { employees }\end{array}$ & & & & & $(.81)$ & \\
\hline 92. Van der Vaart et al. (2015) & $\begin{array}{l}\text { South Africa Various } \\
\text { employees }\end{array}$ & 246 & & & & $\begin{array}{l}.60 \\
(.72)\end{array}$ & \\
\hline 93. Vantilborgh (2015) & Belgium & 215 & .83 & & & .18 & \\
\hline & Various employees & & & & & $(.82)$ & \\
\hline 94. Wu \& Chen (2015) & Taiwan & 258 & .89 & -.41 & & & \\
\hline & High-tech employees & & & $(.91)$ & & & \\
\hline
\end{tabular}


Note:Reliabilities are presented between brackets, however, only 2 out of the 6 studies reported internal reliabilities for turnover.

* Longitudinal study. 


\section{Appendix B: References of Included Studies in the Meta-Analysis}

1. Akhtar, M.N., Bal, M. and Long, L. (2016), "Exit, voice, loyalty, and neglect reactions to frequency of change, and impact of change", Employee Relations, Vol. 38 No. 4, 536562.

2. Arain, G.A., Hameed, I. and Farooq, O. (2012), "Integrating workplace affect with psychological contract breach and employees' attitudes", Global Business and Organizational Excellence, Vol. 31 No. 6, 50-62.

3. Aykan, E. (2014), "Effects of perceived psychological contract breach on turnover intention: Intermediary role of loneliness perception of employees", Procedia- Social and Behavioral Sciences, Vol. 150, pp. 413-419.

4. Bal, P.M., Chiaburu, D. S. and Jansen, P.G.W. (2010), "Psychological contract breach and work performance: Is social exchange a buffer or an intensifier?", Journal of Managerial Psychology, Vol. 25 No. 3, pp. 252-273.

5. Bal, P.M., De Lange, A.H., Jansen, P.G.W. and Van Der Velde, M.E.G. (2013), “A longitudinal study of age-related differences in reactions to psychological contract breach: age and psychological contract breach", Applied Cognitive Psychology, Vol. 62 No.1, pp. 157-181.

6. Bal, P.M., Jansen, P.G.W., Van der Velde, M.E.G., De Lange, A.H. and Rousseau, D.M. (2010), "The role of future time perspective in psychological contracts: a study among older workers", Journal of Vocational Behaviour, Vol. 76, pp. 474-486.

7. Bohle, S, L., Bal, P.M., Jansen, P.G.W., Leiva, P.I. and Alonso, A.M. (2017), "How mass layoffs are related to lower job performance and OCB among surviving employees in Chile: an investigation of the essential role of psychological contract", International Journal of Human Resource Management, Vol. 28 No. 20, pp. 2837-2860. 
8. Bunderson, J.S. (2001), "How work ideologies shape the psychological contracts of professional employees: doctors' responses to perceived breach", Journal of Organizational Behavior, Vol. 22 No. 7, pp. 717-741.

9. Büyükyılmaz, O. and Cakmak, A. (2013), "Direct and indirect effects of psychological contract breach on academicians' turnover intention in Turkey", Journal of Business Economics \& Finance, Vol. 2, pp. 50-66.

10. Carbery, R., Garavan, T. N., O'Brien, F. and McDonnell, J. (2003), "Predicting hotel managers' turnover cognitions", Journal of Managerial Psychology, Vol. 18 No.7, pp. 649-679.

11. Cassar, V., Briner, R.B. and Buttigieg, S. (2016), "What's in a broken promissory obligation? developing and testing a multiple component form measure of psychological contract breach", The International Journal of Human Resource Management, Vol. 27 No. 5, pp. 567-592.

12. Cavanaugh, M.A. and Noe, R.A. (1999), “Antecedents and consequences of relational components of the new psychological contract", Journal of Organizational Behaviour, Vol. 20 No. 3, pp. 323-340.

13. Cesario, S.F., Chambel, M.J. and Guillén, C. (2014), "What if expatriates decide to leave? the mediation effect of the psychological contract fulfilment", Management Research, Vol. 12 No. 2, pp. 03-122.

14. Chambel, M.J. and Alcover, C.M. (2011), “The psychological contract of call-centre workers: employment conditions, satisfaction and civic virtue behaviours", Economic and Industrial Democracy, Vol. 32 No. 1, pp. 115-134. 
PCB AND CULTURE

15. Chen, T. and $\mathrm{Wu}, \mathrm{C}$. (2017), "Improving the turnover intention of tourist hotel employees", International Journal of Contemporary Hospitality Management, Vol. 29 No. 7, pp. 1914-1936.

16. Cheung, M.F., Wong, C. and Yuan, G.Y. (2016), "Why mutual trust leads to highest performance: the mediating role of psychological contract fulfillment", Asia Pacific Journal of Human Resources, Vol. 55 No. 4, pp. 430-453.

17. Clinton, M.E. and Guest, D.E. (2014), "Psychological contract breach and voluntary turnover: testing a multiple mediation model", Journal of Occupational and Organizational Psychology, Vol. 87 No. 1, pp. 200-207.

18. Cohen, A. and Diamant, A. (2017), "The role of justice perceptions in determining counterproductive work behaviors", The International Journal of Human Resource Management, doi: 10.1080/09585192.2017.1340321.

19. Costa, S. and Neves, P. (2017), "Job insecurity and work outcomes: the role of psychological contract breach and positive psychological capital”, Work \& Stress, Vol. 31 No. 4 , pp. 375-394.

20. Coyle-Shapiro, J.A.M. and Kessler, I. (2000), “Consequences of the psychological contract for the employment relationship: a large-scale survey", Journal of Management Studies, Vol. 37 No. 7, pp. 903-930.

21. Coyle-Shapiro, J.A.M. and Kessler, I. (2003), "The employment relationship in the U.K. public sector: a psychological contract perspective", Journal of Public Administration Research and Theory, Vol. 13 No. 2, pp. 213-230.

22. De Cuyper, N. and De Witte, H. (2006), “The impact of job insecurity and contract type on attitudes, well-being and behavioural reports: a psychological contract 
PCB AND CULTURE

perspective”, Journal of Occupational and Organizational Psychology, Vol. 79 No.3, pp. 395-409.

23. De Jong, J., Schalk, R. and Croon, M. (2009), "The role of trust in secure and insecure employment situations: a multiple-group analysis", Economic and Industrial Democracy, Vol. 30 No. 4, pp. 510-538.

24. De Jong, J.P., Schalk, R. and Cuyper, N. (2009), Balanced versus unbalanced psychological contracts in temporary and permanent employment: associations with employee attitudes, Management and Organization Review, Vol. 5 No. 3, pp. 329-351.

25. Dulac, T., Coyle-Shapiro, J., Henderson, D. and Wayne, S. (2008), "Not all responses to breach are the same: the interconnection of social exchange and psychological contract processes in organizations", The Academy of Management Journal, Vol. 51 No. 6, pp. 1079-1098.

26. Freese, C., Heinen, J. and Schalk, R. (1999), “Organisatieverandering en het psychologisch contract, betrokkenheid en intentie tot verloop bij werknemers in de thuiszorg”, Tijdschrift voor Arbeidsvraagstukken, Vol. 15 No. 3, pp. 208-218.

27. Freese, C. and Schalk, R. (2008), "How to measure the psychological contract? a critical criteria-based review of measures", South African Journal of Psychology, Vol. 38 No. 2, pp. 269-286.

28. Gardner, D.G., Huang, G., Niu, X., Pierece, J. L. and Lee, C. (2015), “Organization-based self-esteem, psychological contract fulfillment, and perceived employment opportunities: a test of self-regulatory theory", Human Resource Management, Vol. 54 No. 6, pp. 933-953. 
PCB AND CULTURE

29. Granrose, C. S. and Baccili, P. (2006), "Do psychological contracts include boundaryless or protean careers?”. Career Development International, Vol. 11 No. 2, pp. 163-182.

30. Gregory, D.M., Way, C.F., LeFort, S., Barrett, B.J. and Parfrey, P.S. (2007), “Predictors of registered nurses' organizational commitment and intent to stay", Health care Management Review, Vol. 32 No. 2, pp. 119-127.

31. Griep, Y., Vantilborgh, T., Baillien, E. and Pepermans, R. (2016), “The mitigating role of leader-member exchange when perceiving psychological contract violation: a diary survey study among volunteers". European Journal of Work and Organizational Psychology, Vol. 25 No. 2, pp. 254-271.

32. Guchait, P., Cho, S. and Meurs, J.A. (2015), "Psychological contracts, perceived organizational and supervisor support: investigating the impact on intent to leave among hospitality employees in India", Journal of Human Resources in Hospitality \& Tourism, Vol. 14 No. 3, pp. 290-315.

33. Guerrero, S. (2005), "Measurement of the psychological contract in a french work context (La mesure du contrat psychologique dans un contexte de travail francophone)", Relations industrielles / Industrial Relations, Vol. 60 No.1, pp. 112-144.

34. Hartmann, N.N. and Rutherford, B.N. (2015), "Psychological contract breach's antecedents and outcomes in salespeople: the roles of psychological climate, job attitudes, and turnover intention”, Industrial Marketing Management, Vol. 51, pp. 158-170.

35. Henderson, D.J., Wayne, S.J., Shore, L.M., Bommer, W.H. and Tetrick, L.E. (2008), "Leader--member exchange, differentiation, and psychological contract fulfillment: a multilevel examination”. Journal of Applied Psychology, Vol. 93 No. 6, pp. 1208-1219.

36. Huiskamp, R. and Schalk, R. (2002), "Psychologische contracten in arbeidsrelaties: de stand van zaken in Nederland”, Gedrag en Organisatie, Vol. 15 No. 6, pp. 370-385. 
PCB AND CULTURE

37. Jafri, M.H. (2012), "Influence of psychological contract breach on organizational citizenship behaviour and trust”, Psychological Studies, Vol. 57, pp. 29-36.

38. Johnson, J.L. and O'Leary-Kelly, A.M. (2003), “The effects of psychological contract breach and organizational cynicism: not all social exchange violations are created equal", Journal of Organizational Behavior, Vol. 24 No. 5, pp. 627-647.

39. Kraak, J.M., Lunardo, R., Herrbach, O. and Durrieu, F. (2017), "Promises to employees matter, self-identity too: effects of psychological contract breach and older worker identity on violation and turnover intentions", Journal of Business Research, Vol. 70, pp. 108-117.

40. Lapalme, M.È., Simard, G. and Tremblay, M. (2011), “The influence of psychological contract breach on temporary workers' commitment and behaviors: a multiple agency perspective", Journal of Business Psychology, Vol. 26, pp. 311-324.

41. Lapointe, É., Vandenberghe, C. and Boudrias, J.S. (2013), "Psychological contract breach, affective commitment to organization and supervisor, and newcomer adjustment: a threewave moderated mediation model”. Journal of Vocational Behavior, Vol. 83 No. 3, pp. $528-538$.

42. Larwood, L., Wright, T.A., Desrochers, S. and Dahir, V. (1998), "Extending latent role and psychological contract theories to predict intent to turnover and politics in business organizations", Group \& Organization Management, Vol. 23 No. 2, pp. 100-123.

43. Lee, J., Chaudhry, A. and Tekleab, A.G. (2014), “An interactionist perspective on employee performance as a response to psychological contract breach", Personnel Review, Vol. 43 No. 6, pp. 861-880.

44. Lee, C., Liu, J., Rousseau, D.M., Hui, C. and Chen, Z.X. (2011). "Inducements, contributions, and fulfillment in new employee psychological contracts", Human Resource Management, Vol. 50 No. 2, pp. 201-227. 
PCB AND CULTURE

45. Lemire, L. and Rouillard, C. (2005), “An empirical exploration of psychological contract violation and individual behavior", Journal of Managerial Psychology, Vol. 20 No. 2, pp. $150-163$.

46. Lester, S. W. and Kickul, J. (2001), "Psychological contracts in the 21st century: what employees value most and how well organizations are responding to these expectations", Human Resource Planning, Vol. 24 No.1, pp. 10-21.

47. Lester, S. W., Turnley, W. H., Bloodgood, J. M. and Bolino, M. C. (2002), "Not seeing eye to eye: differences in supervisor and subordinate perceptions of and attributions for psychological contract breach", Journal of Organizational Behaviour, Vol. 23 No.1, 3956.

48. Li, J., Wong, I. A. and Kim, W. G. (2016), "Effects of psychological contract breach on attitudes and performance: the moderating role of competitive climate", International Journal of Hospitality Management, Vol. 55, 1-10.

49. Lo, S. and Aryee, S. (2003), "Psychological contract breach in a Chinese context: an integrative approach”, Journal of Management Studies, Vol. 40 No. 4, pp. 1005-1020.

50. Millard, L.J. and Brewerton, P.M. (1999), "Contractors and their psychological contracts”, British Journal of Management, Vol. 10 No.3, pp. 253-274.

51. Orvis, K.A., Dudley, N.M. and Cortina, J.M. (2008), “Conscientiousness and reactions to psychological contract breach: a longitudinal field study", Journal of Applied Psychology, Vol. 93 No. 5, pp. 1183-1193.

52. Paille, P. and Dufour, M.E. (2013), "Employee responses to psychological contract breach and violation: intentions to leave the job, employer or profession", Journal of Applied Business Research, Vol. 29 No.1, pp. 205-216. 
PCB AND CULTURE

53. Piccoli, B., De Witte, H. and Reisel, W.D. (2017), "Job insecurity and discretionary behaviors: social exchange perspective versus group value model", Scandinavian Journal of Psychology, Vol. 58 No.1, pp. 69-79.

54. Quratulain, S., Khan, A.K., Crawshaw, J.R., Arain, G.A. and Hameed, I. (2018), “A study of employee affective organizational commitment and retention in Pakistan: the roles of psychological contract breach and norms of reciprocity", The International Journal of Human Resource Management, Vol. 29 No.17, pp. 2552-2579.

55. Raja, U., Johns, G. and Ntalianis, F. (2004), “The impact of personality on psychological contracts", The Academy of Management Journal, Vol. 47 No. 3, pp. 350-367.

56. Restubog, S.L.D., Bordia, P. and Tang, R.L. (2007), "Behavioural outcomes of psychological contract breach in a non-western culture: the moderating role of equity sensitivity”, British Journal of Management, Vol. 18 No. 4, pp. 376-386.

57. Restubog, S.L., Bordia, P. and Tang, R.L. (2006), "Effects of psychological contract breach on performance of IT employees: the mediating role of affective commitment", Journal of Occupational and Organizational Psychology, Vol. 79 No. 6, pp. 299-306.

58. Restubog, S.L.D., Bordia, P., Tang, R.L. and Krebs, S.A. (2010), "Investigating the moderating effects of leader-member exchange in the psychological contract breachemployee performance relationship: a test of two competing perspectives", British Journal of Management, Vol. 21 No. 2, pp. 422-437.

59. Restubog, S.L.D., Hornsey, M.J., Bordia, P. and Esposo, S.R. (2008), "Effects of psychological contract breach on organizational citizenship behaviour: insights from the group value model”, Journal of Management Studies, Vol. 45 No.8, pp. 1377-1400.

60. Rigotti, T. (2009), "Enough is enough? threshold models for the relationship between psychological contract breach and job-related attitudes", European Journal of Work and Organizational Psychology, Vol. 18 No. 4, pp. 442-463. 
PCB AND CULTURE

61. Robinson, S. (1996), "Trust and breach of the psychological contract”, Administrative Science Quarterly, Vol. 41 No. 4, pp. 574-599.

62. Robinson, S.L. and Morrison, E.W. (2000), “The development of psychological contract breach and violation: a longitudinal study", Journal of Organizational Behaviour, Vol. 21 No.5, pp. 525-546.

63. Robinson, S.L. and Rousseau, D.M. (1994), "Violating the psychological contract: not the exception but the norm”, Journal of Organizational Behaviour, Vol. 15 No. 3, pp. 245259.

64. Rodwell, J. and Ellershaw, J. (2016), "Fulfill promises and avoid breaches to retain satisfied, committed nurses", Journal of Nursing Scholarship, Vol. 48 No. 4, pp. 406413.

65. Rosen, C.C., Chang, C.H., Johnson, R.E. and Levy, P.E. (2009), "Perceptions of the organizational context and psychological contract breach: assessing competing perspectives", Organizational Behavior and Human Decision Processes, Vol. 108 No.2, pp. $202-217$.

66. Salin, D. and Notelaers, G. (2017), “The effect of exposure to bullying on turnover intentions: the role of perceived psychological contract violation and benevolent behavior", Work \& Stress, Vol. 31 No. 4, pp. 355-374.

67. Schalk, R., Freese, C. and Van den Bosch, J. (1995), "Het psychologisch contract van parttimers en full-timers, Een onderzoek naar de verwachtingen van werknemers over wederzijdse verplichtingen tussen organisatie en werknemer in de arbeidssituatie", Gedrag en Organisatie, Vol. 8 No. 5, pp. 307-317.

68. Shahnawaz, M.G. and Goswami, K. (2011), "Effect of psychological contract violation on organizational commitment, trust and turnover intention in private and public sector Indian organizations", Vision, Vol. 15 No. 3, pp. 209-217. 
PCB AND CULTURE

69. Shih, C. and Chuang, C. (2012), "Individual differences, psychological contract breach, and organizational citizenship behavior: a moderated mediation study", "Asia Pacific Journal of Management, Vol. 30 No. 1, pp. 191-210.

70. Si, S., Wei, F. and Li, Y. (2008), “The effect of organizational psychological contract violation on managers' exit, voice, loyalty and neglect in the Chinese context", International Journal of Human Resource Management, Vol. 19, pp. 932-944.

71. Steve, C.S and Chen, S. (2007), "Perceived psychological contract fulfillment and job attitudes among repatriates", International Journal of Manpower, Vol. 28 No. 6, pp. 474488.

72. Stoner, J., Gallagher, V. and Stoner, C. (2011), “The interactive effects of emotional family support and perceived supervisor loyalty on the psychological contract breach turnover relationship", Journal of Managerial Issues, Vol. 23 No. 2, pp. 124-143.

73. Stoner, J.S. and Gallagher, V.C. (2010), "Who cares? the role of job involvement in psychological contract violation, Journal of Applied Social Psychology, Vol. 40 No. 6, pp. $1490-1514$.

74. Sturges, J., Conway, N., Guest, D. and Liefooghe, A. (2005), "Managing the career deal: the psychological contract as a framework for understanding career management, organizational commitment and work behavior”, Journal of Organizational Behavior, Vol. 26 No.7, pp. 821-838.

75. Suazo, M. (2009), "The mediating role of psychological contract violation on the relations between psychological contract breach and work-related attitudes and behaviors", Journal of Managerial Psychology, Vol. 24 No.2, pp. 136-160.

76. Suazo, M., Turnley, W. and Mai, R. (2005), “The role of perceived violation in determining employees' reactions to psychological contract breach", Journal of Leadership \& Organizational Studies, doi: 10.1177/107179190501200104. 
PCB AND CULTURE

77. Sutton, G. and Griffin, M.A. (2004), "Integrating expectations, experiences, and psychological contract violations: a longitudinal study of new professionals", Journal of Occupational and Organizational Psychology, Vol. 77 No. 4, pp. 493-514.

78. Takase, M., Teraoka, S. and Yabase, K. (2016), "Retaining the nursing workforce: factors contributing to the reduction of nurses' turnover intention in Japan", Journal of Nursing Management, Vol. 24 No. 1, pp. 21-29.

79. Tekleab, A.G., Orvis, K.A. and Taylor, M.S. (2013), "Deleterious consequences of change in newcomers' employer-based psychological contract obligations", Journal of Business and Psychology, Vol. 28 No. 3, pp. 361- 374.

80. Tekleab, A.G. and Taylor, M.S. (2003), “Aren't there two parties in an employment relationship? antecedents and consequences of organization-employee agreement on contract obligations and violations", Journal of Organizational Behaviour, Vol. 24 No.5, pp. 585-608.

81. Tekleab, A.G., Takeuchi, R. and Taylor, M.S. (2005), "Extending the chain of relationships among organizational justice, social exchange, and employee reactions: the role of contract violations, Academy of Management Journal, Vol. 48, No. 1, doi: https://doi.org/10.5465/amj.2005.15993162.

82. Turnley, W.H., Bolino, M.C., Lester, S.W. and Bloodgood, J.M. (2003), “The impact of psychological contract fulfillment on the performance of in-role and organizational citizenship behaviors”, Journal of Management, Vol. 29 No. 2, pp. 187-206.

83. Turnley, W.H. and Feldman, D.C. (1999), "The impact of psychological contract violations on exit, voice, loyalty, and neglect", Human Relations, Vol. 52 No.7, pp. 895-922.

84. Turnley, W.H. and Feldman, D.C. (2000), "Re-examining the effects of psychological contract violations: unmet expectations and job dissatisfaction as mediators", Journal of Organizational Behaviour, Vol. 21 No. 1, pp. 25-42. 
85. Uen, J., Chien, M.S. and Yen, Y.F. (2009), "The mediating effects of psychological contracts on the relationship between human resource systems and role behaviors: a multilevel analysis”, Journal of Business Psychology, Vol. 24 No. 2, pp. 215-223.

86. Van den Heuvel, S., Freese, C., Schalk, R. and Van Assen, M. (2017), "How change information influences attitudes toward change and turnover intention", Leadership \& Organization Development Journal, Vol. 38 No. 3, pp. 398-418.

87. Van der Vaart, L., Linde, B., De Beer, L. and Cockeran, M. (2015), “Employee well being, intention to leave and perceived employability: a psychological contract approach”, South African Journal of Economic and Management Sciences, Vol. 18 No.1, pp. 746-756.

88. Vantilborgh, T. (2015), "Volunteers' reactions to psychological contract fulfillment in terms of exit, voice, loyalty, and neglect behavior", Voluntas: International Journal of Voluntary and Nonprofit Organizations, Vol. 26 No. 2, pp. 604-628.

89. Wu, C.M. and Chen, T.J. (2015), "Psychological contract fulfillment in the hotel workplace: empowering leadership, knowledge exchange, and service performance", International Journal of Hospitality Management, doi:10.1016/j.ijhm.2015.04.008

90. Zagenczyk, T.J., Cruz, K.S., Cheung, J.H., Scott, K.L., Kiewitz, C. and Galloway, B. (2015), "The moderating effect of power distance on employee responses to psychological contract breach", European Journal of Work and Organizational Psychology, Vol. 24 No. 6, pp. 853-865. 


\section{Appendix C: Overview of the Cultural practices scores (based on GLOBE) included in the Meta-Analysis}

\begin{tabular}{|c|c|c|c|c|c|c|}
\hline$\sum^{2}$ & 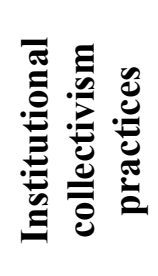 & 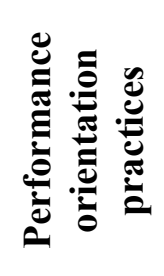 & 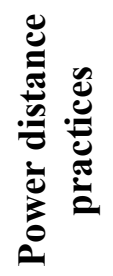 & 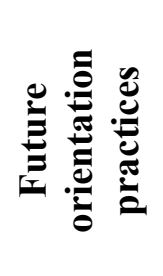 & 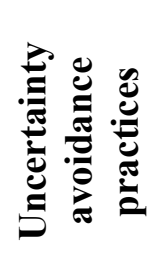 & 窇 \\
\hline $\begin{array}{l}\text { 1. Akhtar et al. } \\
\text { (2016) }\end{array}$ & 4.38 & 4.25 & 5.47 & 4.19 & 4.15 & 2.90 \\
\hline $\begin{array}{l}\text { 2. Arain et al. } \\
\text { (2012) }\end{array}$ & 4.38 & 4.25 & 5.47 & 4.19 & 4.15 & 2.90 \\
\hline $\begin{array}{l}\text { 3. Aykan } \\
(2014)\end{array}$ & 4.03 & 3.83 & 5.57 & 3.74 & 3.63 & 2.89 \\
\hline $\begin{array}{l}\text { 4. Bal et al. } \\
(2010)\end{array}$ & 4.20 & 4.49 & 4.88 & 4.15 & 4.15 & 3.34 \\
\hline $\begin{array}{l}\text { 5. Bal et al. * } \\
(2013)\end{array}$ & 4.46 & 4.32 & 4.11 & 4.61 & 4.70 & 3.50 \\
\hline $\begin{array}{l}\text { 6. Bal et al. } \\
(2010)\end{array}$ & 4.46 & 4.32 & 4.11 & 4.61 & 4.70 & 3.50 \\
\hline $\begin{array}{l}\text { 7. Bohle et al. } \\
\text { (2017) }\end{array}$ & 3.66 & 3.65 & 5.64 & 3.08 & 3.65 & 3.49 \\
\hline $\begin{array}{l}\text { 8. Bunderson * } \\
\text { (2001) }\end{array}$ & 4.20 & 4.49 & 4.88 & 4.15 & 4.15 & 3.34 \\
\hline $\begin{array}{l}\text { 9. Büyükyılmaz \& } \\
\text { Cakmak } \\
(2013)\end{array}$ & 4.03 & 3.83 & 5.57 & 3.74 & 3.63 & 2.89 \\
\hline $\begin{array}{l}\text { 10. Carbery et al. } \\
(2003)\end{array}$ & 4.63 & 4.36 & 5.15 & 3.98 & 4.30 & 3.21 \\
\hline $\begin{array}{l}\text { 11. Cassar et al. } \\
\text { (2016) }\end{array}$ & 4.27 & 4.08 & 5.15 & 4.28 & 4.65 & 3.67 \\
\hline $\begin{array}{l}\text { 12. Cavanaugh \& } \\
\text { Noe (1999) }\end{array}$ & 4.20 & 4.49 & 4.88 & 4.15 & 4.15 & 3.34 \\
\hline $\begin{array}{l}\text { 13. Cesario et al. } \\
\text { (2014) }\end{array}$ & 3.92 & 3.60 & 5.44 & 3.71 & 3.91 & 3.66 \\
\hline $\begin{array}{l}\text { 14. Chambel \& } \\
\text { Alcover (2011) }\end{array}$ & 3.92 & 3.60 & 5.44 & 3.71 & 3.91 & 3.66 \\
\hline $\begin{array}{l}\text { 15. Chen \& Wu } \\
\text { (2017) }\end{array}$ & 4.59 & 4.56 & 5.18 & 3.96 & 4.34 & 3.18 \\
\hline $\begin{array}{l}\text { 16. Cheung et al. } \\
\text { (2016) }\end{array}$ & 4.13 & 4.80 & 4.96 & 4.03 & 4.32 & 3.47 \\
\hline $\begin{array}{l}\text { 17. Clinton \& Guest } \\
\text { (2014) }\end{array}$ & 4.27 & 4.08 & 5.15 & 4.28 & 4.65 & 3.67 \\
\hline $\begin{array}{l}\text { 18. Cohen \& } \\
\text { Diamant (2017) }\end{array}$ & 4.46 & 4.08 & 4.73 & 3.85 & 4.01 & 3.19 \\
\hline $\begin{array}{l}\text { 19. Costa \& Neves } \\
\text { (2017) }\end{array}$ & 3.92 & 3.60 & 5.44 & 3.71 & 3.91 & 3.66 \\
\hline $\begin{array}{l}\text { 20. Coyle-Shapiro } \\
\& \text { Kessler (2000) }\end{array}$ & 4.27 & 4.08 & 5.15 & 4.28 & 4.65 & 3.67 \\
\hline $\begin{array}{l}\text { 21. Coyle-Shapiro } \\
\& \text { Kessler }(2003)\end{array}$ & 4.27 & 4.08 & 5.15 & 4.28 & 4.65 & 3.67 \\
\hline $\begin{array}{l}\text { 22. De Cuper \& De } \\
\text { Witte (2006) }\end{array}$ & 4.46 & 4.32 & 4.11 & 4.61 & 4.70 & 3.50 \\
\hline $\begin{array}{l}\text { 23. De jong et al. } \\
(2009)\end{array}$ & 4.46 & 4.32 & 4.11 & 4.61 & 4.70 & 3.50 \\
\hline $\begin{array}{l}\text { 24. De jong et al. } \\
(2009)\end{array}$ & 4.46 & 4.32 & 4.11 & 4.61 & 4.70 & 3.50 \\
\hline
\end{tabular}




\begin{tabular}{|c|c|c|c|c|c|c|}
\hline $\begin{array}{l}\text { 25. De jong } \\
(2009)\end{array}$ & 4.46 & 4.32 & 4.11 & 4.61 & 4.70 & 3.50 \\
\hline $\begin{array}{l}\text { 26. Dulac et al. * } \\
\text { (2008) }\end{array}$ & 4.46 & 4.32 & 4.11 & 4.61 & 4.70 & 3.50 \\
\hline $\begin{array}{l}\text { 27. Freese et al* } \\
\text { (1999) }\end{array}$ & 4.46 & 4.32 & 4.11 & 4.61 & 4.70 & 3.50 \\
\hline $\begin{array}{l}\text { 28. Freese \& Schalk } \\
\text { (2008) }\end{array}$ & 4.46 & 4.32 & 4.11 & 4.61 & 4.70 & 3.50 \\
\hline $\begin{array}{l}\text { 29. Gardner et al. } \\
(2015)^{*}\end{array}$ & 4.77 & 4.45 & 5.04 & 3.75 & 4.94 & 3.05 \\
\hline $\begin{array}{l}\text { 30. Granrose \& } \\
\text { Baccili (2006) }\end{array}$ & 4.20 & 4.49 & 4.88 & 4.15 & 4.15 & 3.34 \\
\hline $\begin{array}{l}\text { 31. Gregory et al. } \\
(2007)\end{array}$ & 4.38 & 4.49 & 4.82 & 4.44 & 4.58 & 3.70 \\
\hline $\begin{array}{l}\text { 32. Griep et al. * } \\
\text { (2016) }\end{array}$ & 4.46 & 4.32 & 4.11 & 4.61 & 4.70 & 3.50 \\
\hline $\begin{array}{l}\text { 33. Guchait et al. } \\
\text { (2015) }\end{array}$ & 4.38 & 4.25 & 5.47 & 4.19 & 4.15 & 2.90 \\
\hline $\begin{array}{l}\text { 34. Guerrero \& } \\
\text { Herrbach (2005) }\end{array}$ & 3.93 & 4.11 & 5.28 & 3.48 & 4.43 & 3.64 \\
\hline $\begin{array}{l}\text { 35. Hartmann \& } \\
\text { Rutherford (2015) }\end{array}$ & 4.20 & 4.49 & 4.88 & 4.15 & 4.15 & 3.34 \\
\hline $\begin{array}{l}\text { 36. Henderson et al. } \\
\text { (2008) }\end{array}$ & 4.20 & 4.49 & 4.88 & 4.15 & 4.15 & 3.34 \\
\hline $\begin{array}{l}\text { 37. Huiskamp \& } \\
\text { Schalk (2002) }\end{array}$ & 4.46 & 4.32 & 4.11 & 4.61 & 4.70 & 3.50 \\
\hline $\begin{array}{l}\text { 38. Jafri } \\
(2012)\end{array}$ & 4.38 & 4.25 & 5.47 & 4.19 & 4.15 & 2.90 \\
\hline $\begin{array}{l}\text { 39. Johnson \& } \\
\text { O'Leary-Kelly } \\
\text { (2013) }\end{array}$ & 4.20 & 4.49 & 4.88 & 4.15 & 4.15 & 3.34 \\
\hline $\begin{array}{l}\text { 40. Kraak et al. } \\
(2017)\end{array}$ & 4.46 & 4.32 & 4.11 & 4.61 & 4.70 & 3.50 \\
\hline $\begin{array}{l}\text { 41. Lapalme et al. } \\
\text { (2011) }\end{array}$ & 4.38 & 4.49 & 4.82 & 4.44 & 4.58 & 3.70 \\
\hline $\begin{array}{l}\text { 42. Lapointe et al. } \\
\text { (2013) }\end{array}$ & 4.38 & 4.49 & 4.82 & 4.44 & 4.58 & 3.70 \\
\hline $\begin{array}{l}\text { 43. Larwood et al. } \\
\text { (1998) }\end{array}$ & 4.20 & 4.49 & 4.88 & 4.15 & 4.15 & 3.34 \\
\hline $\begin{array}{l}\text { 44. Lee et al. } \\
(2014)\end{array}$ & 4.20 & 4.49 & 4.88 & 4.15 & 4.15 & 3.34 \\
\hline $\begin{array}{l}\text { 45. Lee et al. } \\
\text { (2011) }\end{array}$ & 4.77 & 4.45 & 5.04 & 3.75 & 4.94 & 3.05 \\
\hline $\begin{array}{l}\text { 46. Lemire \& } \\
\text { Rouillard (2005) }\end{array}$ & 4.38 & 4.49 & 4.82 & 4.44 & 4.58 & 3.70 \\
\hline $\begin{array}{l}\text { 47. Lester et al. } \\
(2001)\end{array}$ & 4.20 & 4.49 & 4.88 & 4.15 & 4.15 & 3.34 \\
\hline $\begin{array}{l}\text { 48. Lester et al. } \\
(2002)\end{array}$ & 4.20 & 4.49 & 4.88 & 4.15 & 4.15 & 3.34 \\
\hline $\begin{array}{l}\text { 49. Li et al. } \\
(2016)\end{array}$ & 4.77 & 4.45 & 5.04 & 3.75 & 4.94 & 3.05 \\
\hline $\begin{array}{l}\text { 50. Lo \& Aryee } \\
(2003)\end{array}$ & 4.13 & 4.80 & 4.96 & 4.03 & 4.32 & 3.47 \\
\hline $\begin{array}{l}\text { 51. MIllard \& } \\
\text { Brewerton (1999) }\end{array}$ & 4.27 & 4.08 & 5.15 & 4.28 & 4.65 & 3.67 \\
\hline $\begin{array}{l}\text { 52. Orvis et al. } \\
(2008)^{*}\end{array}$ & 4.20 & 4.49 & 4.88 & 4.15 & 4.15 & 3.34 \\
\hline $\begin{array}{l}\text { 53. Paille \& Dufour } \\
\text { (2013) }\end{array}$ & 4.38 & 4.49 & 4.82 & 4.44 & 4.58 & 3.70 \\
\hline 54. Piccoli et al. & 3.68 & 3.58 & 5.43 & 3.25 & 3.79 & 3.24 \\
\hline
\end{tabular}


(2017)

55. Quratu (2018)

56. Raja et al. $\quad 4.38$

(2004)

57. Restubog et al. $\quad 4.65$

(2007)

58. Restubog et al. $\quad 4.65$

(2007)

59. Restubog et al. $\quad 4.65$

(2006)

60. Restubog et al. $\quad 4.65$

(2010)

61. Restubog et al. $\quad 4.65$

(2010)

62. Restubog * $\quad 4.65$

(2008)

53. Restubog et al. $\quad 4.6$

(2008)*

64. Rigotti

(2009)

*5. Robin

66. Robinson \& 4.2

3.67

4.20

4.25

$5.47 \quad 4.19$

4.15

2.90

Morrison *

(2000)

67. Robinson \& *

4.20

Rousseau (1994) *

4.29

4.25

$5.47 \quad 4.19$

4.15

2.90

68. Rodwell, J. \&

4.29

4.47

$5.44 \quad 4.15$

3.89

3.64

4.47

$5.44 \quad 4.15$

3.89

3.64

4.47

$5.44 \quad 4.15$

3.89

3.64

4.47

$5.44 \quad 4.15$

3.89

3.64

4.47

$5.44 \quad 4.15$

3.89

3.64

4.47

$5.44 \quad 4.15$

3.89

3.64

4.47

$5.44 \quad 4.15$

3.89

3.64

Ellershaw (2016)

69. Rosen et al.

4.20

4.17

$5.39 \quad 4.11$

5.19

3.08

70. Salin \&

4.63

4.49

$4.88 \quad 4.15$

4.15

3.34

4.49

$4.88 \quad 4.15$

4.15

3.34

Notelaers

(2017)

71. Schalk et al. $\quad 4.46$

(1995)

72. Shahnawaz, \&

Goswami (2011)

73. Shahnawaz, \&

Goswami (2011)

74. Shih et al.

(2012)

75. Si et al.

4.38

4.32

4.49

$4.88 \quad 4.15$

4.15

3.34

4.36

$4.74 \quad 4.09$

4.39

3.40

4.49

$4.88 \quad 4.15$

4.15

3.34

3.81

$4.89 \quad 4.24$

5.02

3.35

(2008)

76. Steve \& Cheng (2007)

77. Stoner et al.

4.38

4.25

$4.11 \quad 4.61$

4.70

3.50

4.38

4.25

$5.47 \quad 4.19$

4.15

2.90

(2011) *

78. Stoner et al.

4.59

4.56

$5.47 \quad 4.19$

4.15

2.90

(2010)

79. Sturges et al. (2005)

80. Suazo

4.77

4.45

$5.18 \quad 3.96$

4.34

3.18

(2009)

81. Suazo et al.

(2005)

82. Sutton \&

4.59

4.56

$5.04 \quad 3.75$

4.94

3.05

Griffin*

4.20

4.49

$5.18 \quad 3.96$

4.34

3.18

(2004)

4.20

4.49

$4.88 \quad 4.15$

4.15

3.34

$4.88 \quad 4.15$

4.15

3.34

4.27

4.08

$5.15 \quad 4.28$

4.65

3.67

4.20

4.49

$4.88 \quad 4.15$

4.15

3.34

4.20

4.49

$4.88 \quad 4.15$

4.15

3.34

4.29

4.36

$4.74 \quad 4.09$

4.39

3.40 


\begin{tabular}{|c|c|c|c|c|c|c|}
\hline $\begin{array}{l}\text { 83. Takase et al. } \\
(2016)\end{array}$ & 5.19 & 4.22 & 5.11 & 4.29 & 4.07 & 3.19 \\
\hline $\begin{array}{l}\text { 84. Tekleab et al. } \\
\text { (2013) }\end{array}$ & 4.20 & 4.49 & 4.88 & 4.15 & 4.15 & 3.34 \\
\hline $\begin{array}{l}85 . \text { Tekleab and } \\
\text { Taylor } \\
(2003)\end{array}$ & 4.20 & 4.49 & 4.88 & 4.15 & 4.15 & 3.34 \\
\hline $\begin{array}{l}\text { 86. Tekleab et al. } \\
(2005)\end{array}$ & 4.20 & 4.49 & 4.88 & 4.15 & 4.15 & 3.34 \\
\hline $\begin{array}{l}\text { 87. Turnley et al. } \\
(2003)\end{array}$ & 4.20 & 4.49 & 4.88 & 4.15 & 4.15 & 3.34 \\
\hline $\begin{array}{l}\text { 88. Turnley \& } \\
\text { Feldman } \\
(1999)\end{array}$ & 4.20 & 4.49 & 4.88 & 4.15 & 4.15 & 3.34 \\
\hline $\begin{array}{l}\text { 89. Turnley \& } \\
\text { Feldman } \\
(2000)\end{array}$ & 4.20 & 4.49 & 4.88 & 4.15 & 4.15 & 3.34 \\
\hline $\begin{array}{l}\text { 90. Uen et al. } \\
(2009)\end{array}$ & 4.59 & 4.56 & 5.18 & 3.96 & 4.34 & 3.18 \\
\hline $\begin{array}{l}\text { 91._Van den } \\
\text { Heuvel et al. (2017) }\end{array}$ & 4.46 & 4.32 & 4.11 & 4.61 & 4.70 & 3.50 \\
\hline $\begin{array}{l}\text { 92. Van der Vaart et } \\
\text { al. } \\
(2015)\end{array}$ & 4.50 & 4.38 & 4.63 & 4.38 & 4.34 & 3.46 \\
\hline $\begin{array}{l}\text { 93. Vantilborgh } \\
\text { (2015) }\end{array}$ & 4.46 & 4.32 & 4.11 & 4.61 & 4.70 & 3.50 \\
\hline $\begin{array}{l}\text { 94. Wu \& Chen } \\
\text { (2015) }\end{array}$ & 4.59 & 4.56 & 5.18 & 3.96 & 4.34 & 3.18 \\
\hline $\begin{array}{l}\text { 95. Zagenczyk et al. } \\
(2015) *\end{array}$ & 4.20 & 4.49 & 4.88 & 4.15 & 4.15 & 3.34 \\
\hline
\end{tabular}

Please note: Longitudinal study * 